Article

\title{
Hybrid Electromagnetic Nanomaterials Based on Polydiphenylamine-2-carboxylic Acid
}

\author{
Sveta Zhiraslanovna Ozkan ${ }^{1, *}$ (), Aleksandr Ivanovich Kostev ${ }^{1}$, Galina Petrovna Karpacheva ${ }^{1}$, \\ Petr Aleksandrovich Chernavskii ${ }^{1,2}$, Andrey Aleksandrovich Vasilev ${ }^{1}[\mathbb{D}$ and \\ Dmitriy Gennad'evich Muratov ${ }^{1}$ \\ 1 A.V. Topchiev Institute of Petrochemical Synthesis, Russian Academy of Sciences, 29 Leninsky Prospect, \\ 119991 Moscow, Russia; kostev@ips.ac.ru (A.I.K.); gpk@ips.ac.ru (G.P.K.); chern5@inbox.ru (P.A.C.); \\ vasilev@ips.ac.ru (A.A.V.); muratov@ips.ac.ru (D.G.M.) \\ 2 Department of Chemistry Lomonosov Moscow State University, 1-3 Leninskie Gory, 119991 Moscow, Russia \\ * Correspondence: ozkan@ips.ac.ru
}

Received: 18 June 2020; Accepted: 12 July 2020; Published: 15 July 2020

\begin{abstract}
Hybrid ternary nanomaterials based on conjugated polymer polydiphenylamine-2carboxylic acid (PDPAC) (poly- $N$-phenylanthranilic acid), $\mathrm{Fe}_{3} \mathrm{O}_{4}$ nanoparticles and single-walled carbon nanotubes (SWCNT) were prepared for the first time. Polymer-metal-carbon $\mathrm{Fe}_{3} \mathrm{O}_{4} / \mathrm{SWCNT} /$ PDPAC nanocomposites were synthesized via in situ oxidative polymerization of diphenylamine-2 -carboxylic acid (DPAC) by two different ways: in an acidic medium and in the interfacial process in an alkaline medium. In an alkaline medium ( $\mathrm{pH}$ 11.4), the entire process of $\mathrm{Fe}_{3} \mathrm{O}_{4} / \mathrm{SWCNT} / \mathrm{PDPAC}-1$ synthesis was carried out in one reaction vessel without intermediate stages of product extraction and purification. In an acidic medium ( $\mathrm{pH}$ 0.3), to prepare the $\mathrm{Fe}_{3} \mathrm{O}_{4} / \mathrm{SWCNT} / \mathrm{PDPAC}-2$ nanocomposites, prefabricated magnetite nanoparticles were deposited on the surface of obtained SWCNT/PDPAC-2. The phase composition of the nanocomposites does not depend on the synthesis reaction medium $\mathrm{pH}$. The influence of the reaction medium $\mathrm{pH}$ on the structure, morphology, thermal, magnetic, and electrical properties of the obtained ternary nanocomposites was studied.
\end{abstract}

Keywords: polydiphenylamine-2-carboxylic acid; conjugated polymers; polymer-metal-carbon nanocomposites; in situ oxidative polymerization; single-walled carbon nanotubes; $\mathrm{Fe}_{3} \mathrm{O}_{4}$ nanoparticles; magnetic fluids; electromagnetic nanomaterials

\section{Introduction}

Modern technology demands the creation of new generation materials with a range of required properties. In recent decades, polymer nanocomposites have become a prominent area of current research promoted by rapid developments in both polymer science and nanotechnology [1-6]. Polymer nanocomposites have unique physicochemical properties owing to synergistic performance derived from each component. Such materials are of growing interest to researchers due to their great potentials for a wide range of applications [7-16]. Polymer-metal-carbon nanocomposites containing conjugated polymers, magnetic nanoparticles and carbon nanomaterials take a special place in this class of polymer nanocomposites [17,18]. Such ternary nanocomposites are superparamagnetic [19-22] and can effectively absorb electromagnetic radiation [20-27]. Due to the combination of their electrical and magnetic properties, these electromagnetic nanocomposites can be used for medical applications (immobilization of trypsin in a nanocomposite for protein digestion) [28]; to produce sensors [29]; supercapacitors [30-32]; as cathode materials for rechargeable batteries and fuel cells [33-35]; and as anticorrosive coatings [36]. 
Polyaniline, polypyrrole, polythiophene, and their derivatives are examples of conjugated polymers used to synthesize ternary nanocomposites. Graphene [30-32], reduced graphene oxide (RGO) $[25,27,29,30,36,37]$, and carbon nanotubes (CNT) $[19,21,26,35,38-40]$ can be used as carbonaceous nanofillers. The choice of carbon nanomaterials is explained by their excellent structural and functional properties [41,42]. Ternary nanocomposites use $\mathrm{Fe}_{3} \mathrm{O}_{4}[19,21,26,27,36,38-40], \mathrm{Co}_{3} \mathrm{O}_{4}[25,30,32]$, $\mathrm{Fe}_{2} \mathrm{O}_{3}$ [29,37], $\mathrm{FeCoO}$ [35], and $\mathrm{CoFe}_{2} \mathrm{O}_{4}$ [31] as magnetic nanoparticles.

There are two most common approaches to the preparation of polymer-metal-carbon nanocomposites. The first way is the in situ oxidative polymerization of aromatic amines in the presence of magnetic nanoparticles immobilized on the surface of carbon nanomaterials $[19,20,23,29,39,40]$. The second approach provides the in situ oxidative polymerization of aromatic amines in the presence of carbon nanomaterials followed by the deposition of magnetic nanoparticles on the polymer surface $[21,22,25,38]$. Depending on the synthesis way, prefabricated magnetite nanoparticles uniform in size and shape were used to synthesize the $\mathrm{Fe}_{3} \mathrm{O}_{4} / \mathrm{MWCNT}$ and $\mathrm{Fe}_{3} \mathrm{O}_{4} / \mathrm{RGO}$ nanocomposites $[19,20,23]$. Graphene oxide was reduced with hydrazine $[20,22,25]$. Multi-walled carbon nanotubes (MWCNT) were pretreated with concentrated acids to functionalize their surface [21,23]. Modified $\mathrm{Fe}_{3} \mathrm{O}_{4}$ nanoparticles were added to the reaction solution containing MWCNT/PANI [21].

Earlier, we obtained hybrid nanomaterials based on poly-3-amine-7-methylamine-2-methylphenazine (PAMMP), single-walled carbon nanotubes (SWCNT), and $\mathrm{Fe}_{3} \mathrm{O}_{4}$ nanoparticles via in situ chemical oxidative polymerization of 3-amine-7-methylamine-2-methylphenazine hydrochloride (Neutral Red) in the presence of prefabricated $\mathrm{Fe}_{3} \mathrm{O}_{4} / \mathrm{SWCNT}$ nanocomposites [43]. The $\mathrm{Fe}_{3} \mathrm{O}_{4} / \mathrm{SWCNT} / \mathrm{PAMMP}$ nanomaterials are superparamagnetic.

In the present study, ternary nanocomposites based on polydiphenylamine-2-carboxylic acid (PDPAC), $\mathrm{Fe}_{3} \mathrm{O}_{4}$ nanoparticles, and SWCNT were prepared for the first time. The $\mathrm{Fe}_{3} \mathrm{O}_{4} / \mathrm{SWCNT} / \mathrm{PDPAC}$ nanomaterials were synthesized under different conditions of oxidative polymerization: in the interfacial process in an alkaline medium ( $\mathrm{pH} 11.4$ ) and in a $5 \mathrm{M}$ solution of sulfuric acid ( $\mathrm{pH}$ 0.3). A comparative analysis of the structure, morphology, thermal, magnetic, and electrical properties depending on the synthesis conditions was done.

\section{Experimental}

\subsection{Materials}

Diphenylamine-2-carboxylic acid ( $\mathrm{N}$-phenylanthranilic acid) $\left(\mathrm{C}_{13} \mathrm{H}_{11} \mathrm{O}_{2} \mathrm{~N}\right)$ (analytical grade), sulfuric acid (reagent grade), aqueous ammonia (reagent grade), and chloroform (reagent grade), as well as iron (II) sulfate (high-purity grade) and iron (III) chloride (high-purity grade) were used as received. Ammonium persulfate (analytical grade) was purified by recrystallization from distilled water. The aqueous solutions of reagents were prepared with the use of distilled water. SWCNT from Carbon Chg, Ltd. (Moscow, Russia) were produced using the electric arc discharge technique with a $\mathrm{Ni} / \mathrm{Y}$ catalyst $(d=1.4-1.6 \mathrm{~nm}, l=0.5-1.5 \mu \mathrm{m})$.

\subsection{Synthesis of $\mathrm{Fe}_{3} \mathrm{O}_{4} / \mathrm{SWCNT}$}

The synthesis of $\mathrm{Fe}_{3} \mathrm{O}_{4}$ nanoparticles immobilized on the SWCNT surface was carried out via hydrolysis of iron (II) and (III) salts mixture with a molar ratio of 1:2 in a solution of ammonium hydroxide in the presence of SWCNT at $60{ }^{\circ} \mathrm{C}$. For that, $0.86 \mathrm{~g}$ of $\mathrm{FeSO}_{4} \cdot 7 \mathrm{H}_{2} \mathrm{O}$ and $2.35 \mathrm{~g}$ of $\mathrm{FeCl}_{3} \cdot 6 \mathrm{H}_{2} \mathrm{O}$ were dissolved in $20 \mathrm{~mL}$ of distilled water (Table 1). $0.03 \mathrm{~g}$ of SWCNT were added to the resulting solution and heated to $60^{\circ} \mathrm{C}$, then $5 \mathrm{~mL}$ of ammonium hydroxide $\mathrm{NH}_{4} \mathrm{OH}$ were added. The resulting suspension was heated on a steam bath to $80^{\circ} \mathrm{C}$ and stirred for $0.5 \mathrm{~h}$. The suspension was cooled at ambient temperature under intensive stirring for $1 \mathrm{~h}$. The obtained $\mathrm{Fe}_{3} \mathrm{O}_{4} / \mathrm{SWCNT}$ nanocomposite was filtered off, washed with distilled water until neutral reaction of the filtrate, and vacuum-dried over $\mathrm{KOH}$ to constant weight. 
Table 1. Conditions for synthesis of $\mathrm{Fe}_{3} \mathrm{O}_{4} / \mathrm{SWCNT}$ and $\mathrm{Fe}_{3} \mathrm{O}_{4} / \mathrm{SWCNT} / \mathrm{PDPAC}$ nanocomposites.

\begin{tabular}{|c|c|c|c|c|c|c|}
\hline \multirow{2}{*}{$\begin{array}{l}\text { Nanomaterials } \\
\text { Abbreviations }\end{array}$} & \multirow{2}{*}{$\mathrm{Fe}, \%$ * } & \multirow{2}{*}{ Preparation Method } & \multirow{2}{*}{$\begin{array}{c}* * \text { Amount of } \\
\text { SWCNT, g }\end{array}$} & \multirow{2}{*}{ Amount of DPAC, $g$} & \multicolumn{2}{|c|}{$* * *$ Amount of Iron Salts, $\mathrm{g}$} \\
\hline & & & & & Fe (II) & Fe (III) \\
\hline $\mathrm{F}_{34} \mathrm{C}_{3} * * * *$ & 61.2 & $\begin{array}{l}\text { Synthesis of } \mathrm{Fe}_{3} \mathrm{O}_{4} / \mathrm{SWCNT} \text { in } \\
\text { an alkaline medium }\end{array}$ & 0.03 & 0 & 0.86 & 2.35 \\
\hline $\mathrm{F}_{34} \mathrm{C}_{3} \mathrm{P}-1$ & 33.5 & \multirow{5}{*}{$\begin{array}{l}\text { Polymerization of DPAC in the } \\
\text { interfacial process in an } \\
\text { alkaline medium } \\
\text { with } \mathrm{Fe}_{3} \mathrm{O}_{4} / \mathrm{SWCNT}\end{array}$} & \multirow{4}{*}{0.03} & \multirow{5}{*}{1.0} & 0.86 & 2.35 \\
\hline $\mathrm{F}_{18} \mathrm{C}_{3} \mathrm{P}-1$ & 17.9 & & & & 0.43 & 1.18 \\
\hline $\mathrm{F}_{14} \mathrm{C}_{3} \mathrm{P}-1$ & 12.0 & & & & 0.22 & 0.59 \\
\hline $\mathrm{F}_{7} \mathrm{C}_{3} \mathrm{P}-1$ & 6.4 & & & & \multirow{2}{*}{0.11} & \multirow{2}{*}{0.29} \\
\hline $\mathrm{F}_{7} \mathrm{C}_{10} \mathrm{P}-1$ & 8.4 & & 0.1 & & & \\
\hline $\mathrm{F}_{34} \mathrm{C}_{3} \mathrm{P}-2$ & 34.7 & \multirow{5}{*}{$\begin{array}{c}\text { Precipitation of } \mathrm{Fe}_{3} \mathrm{O}_{4} \text { onto the } \\
\text { surface of the SWCNT/PDPAC, } \\
\text { prepared in } \\
\text { an acidic medium }\end{array}$} & \multirow{4}{*}{0.019} & \multirow{5}{*}{0.64} & 0.43 & 1.18 \\
\hline $\mathrm{F}_{18} \mathrm{C}_{3} \mathrm{P}-2$ & 17.8 & & & & 0.27 & 0.73 \\
\hline $\mathrm{F}_{14} \mathrm{C}_{3} \mathrm{P}-2$ & 13.4 & & & & 0.11 & 0.29 \\
\hline $\mathrm{F}_{7} \mathrm{C}_{3} \mathrm{P}-2$ & 7.6 & & & & 0.054 & 0.15 \\
\hline $\mathrm{F}_{7} \mathrm{C}_{10} \mathrm{P}-2$ & 6.2 & & 0.064 & & & \\
\hline
\end{tabular}




\subsection{Preparation of $\mathrm{Fe}_{3} \mathrm{O}_{4} / \mathrm{SWCNT/PDPAC} \mathrm{Nanocomposites}$}

2.3.1. Preparation of $\mathrm{Fe}_{3} \mathrm{O}_{4} /$ SWCNT/PDPAC Nanocomposites in the Interfacial Process in an Alkaline Medium

The following method was used to prepare the $\mathrm{Fe}_{3} \mathrm{O}_{4} / \mathrm{SWCNT} / \mathrm{PDPAC}$ nanocomposite in the interfacial process in an alkaline medium. First, the synthesis of $\mathrm{Fe}_{3} \mathrm{O}_{4}$ nanoparticles of the required concentration, immobilized on the surface of SWCNT, was carried out as described in 2.2 at $55^{\circ} \mathrm{C}$. The amount of carbon nanotubes is $\mathrm{C}_{\mathrm{SWCNT}}=3$ and $10 \mathrm{wt}$. \% relative to the monomer weight. Diphenylamine-2-carboxylic acid (DPAC) solution with the required concentration $(0.15 \mathrm{~mol} / \mathrm{L}, 1 \mathrm{~g})$ in a mixture of an organic solvent-chloroform $(60 \mathrm{~mL})$ and $\mathrm{NH}_{4} \mathrm{OH}(5 \mathrm{~mL})$ - was added to the obtained aqueous alkaline suspension of the $\mathrm{Fe}_{3} \mathrm{O}_{4} / \mathrm{SWCNT}$ nanocomposite. The process was conducted at $55^{\circ} \mathrm{C}$ with continuous intensive stirring for $0.5 \mathrm{~h}$. The suspension was cooled at room temperature with vigorous stirring for $1 \mathrm{~h}$. After that, the suspension was thermostated under continuous stirring at $0{ }^{\circ} \mathrm{C}$, and the aqueous solution of ammonium persulfate $(0.3 \mathrm{~mol} / \mathrm{L}, 1.96 \mathrm{~g})$ was added. The solutions of the organic and aqueous phases were mixed in one shot without gradual dosing of the reagents. The volume ratio of organic and aqueous phases was 1:1 $\left(V_{\text {total }}=120 \mathrm{~mL}\right)$. The polymerization reaction continued for $3 \mathrm{~h}$ under intensive stirring at $0{ }^{\circ} \mathrm{C}$. When the synthesis was completed, the reaction mixture was precipitated in a threefold excess of $1 \mathrm{M} \mathrm{H}_{2} \mathrm{SO}_{4}$. The obtained product was filtered off and washed repeatedly with distilled water until neutral reaction of the filtrate. Since the product was in a neutral basic form, it was vacuum dried over alkali $(\mathrm{KOH})$ to constant weight. The yield was $1.058 \mathrm{~g}$ for the nanocomposite prepared at $\mathrm{C}_{\mathrm{FeSO} 4 \cdot 7 \mathrm{H} 2 \mathrm{O}}=0.86 \mathrm{~g}$ and $\mathrm{C}_{\mathrm{FeCl} 3 \cdot 6 \mathrm{H} 2 \mathrm{O}}=2.35 \mathrm{~g}, \mathrm{C}_{\mathrm{SWCNT}}=0.03 \mathrm{~g}$ ( $3 \mathrm{wt.} \%$ relative to the monomer weight).

Nanocomposites based on PDPAC, SWCNT, and magnetite nanoparticles obtained in an alkaline medium were marked as $\mathrm{Fe}_{3} \mathrm{O}_{4} / \mathrm{SWCNT} / \mathrm{PDPAC}-1$. PDPAC was synthesized under the same conditions [44] to compare the structure and properties of nanocomposites and polymer, and marked as PDPAC-1.

The $\mathrm{Fe}_{3} \mathrm{O}_{4} / \mathrm{SWCNT/PDPAC}-1$ nanocomposites depending on synthesis conditions in alkaline medium were marked as $\boldsymbol{F}_{\boldsymbol{x}} \boldsymbol{C}_{\boldsymbol{y}} \boldsymbol{P} \mathbf{- 1}$, where $\boldsymbol{F}-\mathrm{Fe}_{3} \mathrm{O}_{4}, \boldsymbol{C}$-SWCNT, $\boldsymbol{P}$-PDPAC, $\boldsymbol{x}$ - the iron content according to ICP-AES data, and $y$-the SWCNT content relative to the monomer weight (Table 1).

\subsubsection{Preparation of $\mathrm{Fe}_{3} \mathrm{O}_{4} / \mathrm{SWCNT} / \mathrm{PDPAC}$ Nanocomposites in an Acid Medium}

The following method was used to prepare the $\mathrm{Fe}_{3} \mathrm{O}_{4} / \mathrm{SWCNT} / \mathrm{PDPAC}$ nanocomposite in an acidic medium. First, the SWCNT/PDPAC nanocomposite was synthesized. For that, SWCNT were added to the solution of DPAC $(0.1 \mathrm{~mol} / \mathrm{L}, 0.64 \mathrm{~g})$ in $5 \mathrm{M} \mathrm{H}_{2} \mathrm{SO}_{4}$ and stirred in an ultrasonic bath at room temperature for $0.5 \mathrm{~h}$. The mixture was heated to $25^{\circ} \mathrm{C}$. The amount of carbon nanotubes was $\mathrm{C}_{\text {SWCNT }}=3$ and $10 \mathrm{wt}$. $\%$ relative to the monomer weight. Then, for the oxidative polymerization of DPAC in the presence of SWCNT, an aqueous solution of ammonium persulfate $(0.2 \mathrm{~mol} / \mathrm{L}, 1.368 \mathrm{~g})$ in the same solvent $\left(1 / 4\right.$ of total volume, $\left.V_{\text {total }}=30 \mathrm{~mL}\right)$ was added dropwise to the suspension previously thermostated at $0{ }^{\circ} \mathrm{C}$ under continuous stirring. The synthesis was carried out during $3 \mathrm{~h}$ under intensive stirring at $0{ }^{\circ} \mathrm{C}$. When the reaction was completed, the mixture was precipitated in $200 \mathrm{~mL}$ of distilled water. The obtained SWCNT/PDPAC nanocomposite was filtered off and washed repeatedly with distilled water until there was neutral reaction of the filtrate. The synthesis of $\mathrm{Fe}_{3} \mathrm{O}_{4}$ nanoparticles was carried out by a known method via hydrolysis of iron (II) and (III) salts mixture in a solution of ammonium hydroxide [45]. To synthesize $\mathrm{Fe}_{3} \mathrm{O}_{4}$ nanoparticles of the required concentration, $\mathrm{FeSO}_{4} \cdot 7 \mathrm{H}_{2} \mathrm{O}$ and $\mathrm{FeCl}_{3} \cdot 6 \mathrm{H}_{2} \mathrm{O}$ with a molar ratio of 1:2 were dissolved in $20 \mathrm{~mL}$ of distilled water and heated to $60^{\circ} \mathrm{C}$, then $5 \mathrm{~mL}$ of ammonium hydroxide $\mathrm{NH}_{4} \mathrm{OH}$ were added. The reaction mixture was heated on a steam bath to $80^{\circ} \mathrm{C}$ and stirred for $0.5 \mathrm{~h}$. Freshly prepared SWCNT/PDPAC nanocomposite was added immediately, without preliminary drying, to the obtained $\mathrm{Fe}_{3} \mathrm{O}_{4}$ suspension. The reaction mixture was stirred in an ultrasonic bath at ambient temperature for $0.5 \mathrm{~h}$; then, to remove the liquid phase, it was heated to $60^{\circ} \mathrm{C}$ in a crystallizing pan until precipitation. The obtained product was 
filtered off, washed repeatedly with distilled water to an uncolored filtrate, and to avoid dedoping, vacuum dried over $\mathrm{CaCl}_{2}$ to constant weight. The yield was $0.82 \mathrm{~g}$ for the nanocomposite prepared at $\mathrm{C}_{\mathrm{FeSO} 4 \cdot 7 \mathrm{H} 2 \mathrm{O}}=0.43 \mathrm{~g}$ and $\mathrm{C}_{\mathrm{FeCl} 3} \cdot 6 \mathrm{H} 2 \mathrm{O}=1.175 \mathrm{~g}$, with $\mathrm{C}_{\mathrm{SWCNT}}=0.019 \mathrm{~g}$ ( $3 \mathrm{wt}$. \% relative to the monomer weight).

Nanocomposites based on PDPAC, SWCNT, and magnetite nanoparticles obtained in an acidic medium were marked as $\mathrm{Fe}_{3} \mathrm{O}_{4} / \mathrm{SWCNT/PDPAC-2}$. To compare the structure and properties of nanocomposites and polymer, PDPAC was synthesized under the same conditions [46,47] and marked as PDPAC-2.

The $\mathrm{Fe}_{3} \mathrm{O}_{4} / \mathrm{SWCNT} / \mathrm{PDPAC}-2$ nanocomposites depending on synthesis conditions in acidic medium were marked as $\boldsymbol{F}_{x} \boldsymbol{C}_{y} \boldsymbol{P}$-2, where $\boldsymbol{F}-\mathrm{Fe}_{3} \mathrm{O}_{4}, \boldsymbol{C}$-SWCNT, $\boldsymbol{P}$-PDPAC, $\boldsymbol{x}$ - the iron content according to ICP-AES data, and $y$-the SWCNT content relative to the monomer weight (Table 1).

\subsection{Preparation of Suspensions for Magnetic Fluids}

The suspensions of the $\mathrm{Fe}_{3} \mathrm{O}_{4} / \mathrm{SWCNT}$ and $\mathrm{Fe}_{3} \mathrm{O}_{4} / \mathrm{SWCNT} / \mathrm{PDPAC}$ nanocomposites in ethanol were prepared. For this, $0.01 \mathrm{~g}$ of the nanocomposite was added to $5 \mathrm{~mL}$ of ethanol, mixed thoroughly, and left in a closed vessel to prevent evaporation of the solvent.

\subsection{Characterization}

The molecular mass of diphenylamine-2-carboxylic acid polymers was measured by GPC using Water's 150C chromatograph (San Diego, CA, USA) equipped with PLgel $5 \mu \mathrm{m}$ MIXED-C GPC columns (Santa Clara, CA, USA), using N-methylpyrrolidone as an eluent at $60^{\circ} \mathrm{C}$. The eluent flow rate was $1 \mathrm{~mL} / \mathrm{min}$. Volume of the injected sample was $150 \mathrm{~mL}$. Calibration was performed on polystyrene. RI-detector was used. Accuracy of MM definition is $\sim 5 \%$.

The metal content in the nanocomposites was measured quantitatively by an inductively coupled plasma atomic emission spectroscopy method (ICP-AES) using a Shimadzu ICP emission spectrometer (ICPE-9000).

FTIR spectra were measured in air on a Bruker IFS 66v FTIR spectrometer (Karlsruhe, Germany) in the range of $400-4000 \mathrm{~cm}^{-1}$ and analyzed with Soft-Spectra software. The samples were prepared as $\mathrm{KBr}$ pressed pellets. Attenuated total reflection (ATR) FTIR spectra of the samples in the attenuated total reflectance mode were recorded using a HYPERION-2000 IR microscope (Bruker, Karlsruhe, Germany) coupled with the Bruker IFS 66v FTIR spectrometer in the range of $600-4000 \mathrm{~cm}^{-1}$ (150 scans, ZnSe crystal, resolution of $2 \mathrm{~cm}^{-1}$ ).

An X-ray diffraction study was performed in ambient atmosphere using a Difray-401 X-ray diffractometer (Scientific Instruments Joint Stock Company, Saint-Petersburg, Russia) with Bragg-Brentano focusing on $\mathrm{CrK}_{\alpha}$ radiation, $\lambda=0.229 \mathrm{~nm}$. The results of $X$-ray diffraction analysis were used to calculate the size distribution of the coherent scattering regions of crystallites [48] in magnetic nanoparticles.

An electron microscopic study was performed using a LEO912 AB OMEGA transmission electron microscope (Bioz Inc., Los Altos, CA, USA) and a Hitachi TM 3030 scanning electron microscope (Hitachi High-Technologies Corporation, Fukuoka, Japan) with magnification up to 30,000 and $30 \mathrm{~nm}$ resolution. The size of nanoparticles is determined using the EsiVision software (eVision Software, The Hague, The Netherlands).

A vibration magnetometer was used to study the magnetic characteristics of the systems. The cell of the vibration magnetometer was designed as a flow quartz microreactor, which made it possible to study chemical transformations in the in situ mode [49]. Specific magnetization depending on the magnetic field value was measured; magnetic characteristics of the samples at room temperature were determined.

The AC conductivity was measured with a 6367A precision LCR-meter (Microtest Co., Ltd., New Taipei City, Taiwan) in the frequency range of $0.1 \mathrm{~Hz}-1.0 \mathrm{MHz}$. 
Thermogravimetric analysis (TGA) was performed on a Mettler Toledo TGA/DSC1 (Giessen, Germany) in the dynamic mode in the range of $30-1000{ }^{\circ} \mathrm{C}$ in air and in the argon flow. The weight of the samples was $100 \mathrm{mg}$, the heating rate was $10^{\circ} \mathrm{C} / \mathrm{min}$, and the argon flow velocity was $10 \mathrm{~mL} / \mathrm{min}$. Calcined aluminum oxide was used as a reference. The samples were analyzed in an $\mathrm{Al}_{2} \mathrm{O}_{3}$ crucible.

Differential scanning calorimetry (DSC) was performed on a Mettler Toledo DSC823e calorimeter (Giessen, Germany). The samples were heated at the rate of $10{ }^{\circ} \mathrm{C} / \mathrm{min}$ in the nitrogen atmosphere, with the nitrogen flow rate of $70 \mathrm{~mL} / \mathrm{min}$. The measurement results were processed with the service program STARe supplied with the device.

\section{Results and Discussion}

\subsection{Synthesis and Characterization of Nanomaterials}

Synthesis methods were developed to prepare polymer-metal-carbon nanocomposites based on polydiphenylamine-2-carboxylic acid (PDPAC) first synthesized by the authors [44,46], single-walled carbon nanotubes (SWCNT), and magnetite nanoparticles $\left(\mathrm{Fe}_{3} \mathrm{O}_{4}\right)$. Hybrid $\mathrm{Fe}_{3} \mathrm{O}_{4} / \mathrm{SWCNT} / \mathrm{PDPAC}$ nanomaterials were synthesized via in situ oxidative polymerization of diphenylamine-2-carboxylic acid (DPAC) in an acidic medium and in the interfacial process in an alkaline medium. Table 1 presents the conditions for synthesis of the nanocomposites. For comparison, polymers of diphenylamine-2carboxylic acid were synthesized under the same conditions: in a $\mathrm{NH}_{4} \mathrm{OH}$ solution in the presence of chloroform (PDPAC-1) and in $5 \mathrm{M} \mathrm{H}_{2} \mathrm{SO}_{4}$ (PDPAC-2). According to the GPC, the molecular mass of PDPAC- 1 reached $M_{w}=2.6 \times 10^{4}$, the degree of polymerization was more than 120, and the polydispersity index was 2.2 [44]. The PDPAC-2 molecular mass achieved $M_{w}=1.1 \times 10^{4}$, the polymerization degree was above 50 , and the index of polydispersity was 2.0 [46]. The oxidative polymerization in the heterophase system in the presence of chloroform reduces the probability of oxidative hydrolysis and macromolecules destruction owing to separation of reaction products and the oxidizer. This makes it possible to increase the molecular mass of PDPAC- 1 by a factor of nearly 2.5 as compared to the homogeneous process.

Figure 1 shows the sequence of synthesis steps of the ternary nanomaterials.

In an alkaline medium ( $\mathrm{pH}$ 11.4), the entire process of $\mathrm{Fe}_{3} \mathrm{O}_{4} / \mathrm{SWCNT} / \mathrm{PDPAC}-1$ synthesis was carried out in one reaction vessel without intermediate stages of disengagement and purification. The synthesis of $\mathrm{Fe}_{3} \mathrm{O}_{4}$ nanoparticles; their immobilization on the surface of SWCNT with the formation of $\mathrm{Fe}_{3} \mathrm{O}_{4} / \mathrm{SWCNT}$ nanocomposite; the anchorage of a monomer to $\mathrm{Fe}_{3} \mathrm{O}_{4} / \mathrm{SWCNT}$ by adding a DPAC solution in a mixture of chloroform and $\mathrm{NH}_{4} \mathrm{OH}$; and in situ interfacial oxidative polymerization in the presence of ammonium persulfate were performed stepwise (Figure 1a).

In an acidic medium ( $\mathrm{pH} 0.3$ ), to prepare the $\mathrm{Fe}_{3} \mathrm{O}_{4} / \mathrm{SWCNT} / \mathrm{PDPAC}-2$ nanocomposites, the in situ oxidative polymerization of DPAC in the presence of SWCNT was performed followed by the deposition of prefabricated magnetite nanoparticles on the surface of obtained SWCNT/PDPAC-2 (Figure 1b).

The formation of $\mathrm{Fe}_{3} \mathrm{O}_{4} / \mathrm{SWCNT/PDPAC}$ nanocomposite materials was confirmed by X-ray diffraction (XRD), FTIR spectroscopy, transmission electron microscopy (TEM), and scanning electron microscopy (SEM). 


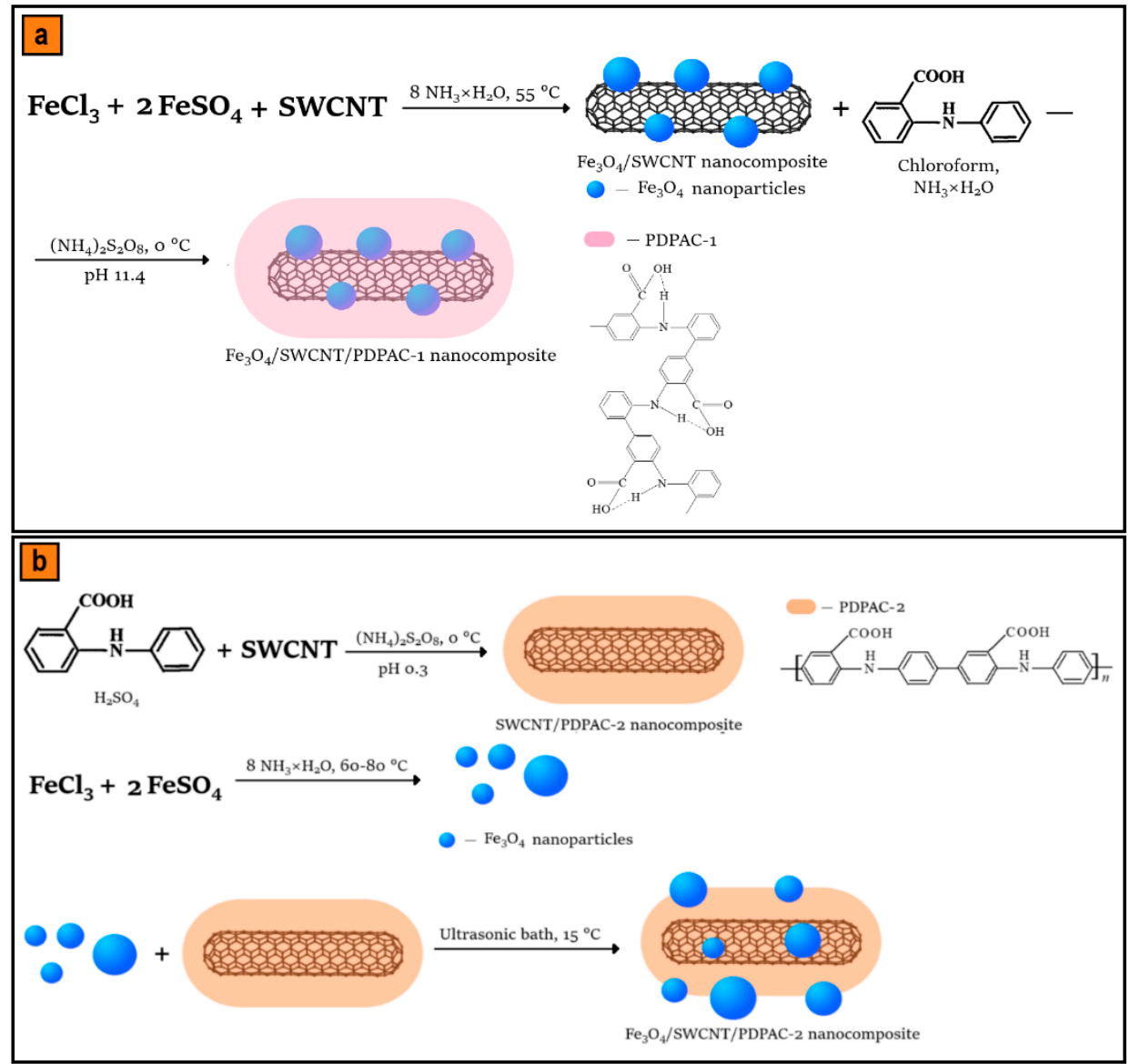

Figure 1. Synthesis sequence of $\mathrm{Fe}_{3} \mathrm{O}_{4} / \mathrm{SWCNT/PDPAC}$ in alkaline (a) and acidic media (b).

The data presented in Figure 2 allow us to conclude that the phase composition of the nanocomposites does not depend on the synthesis reaction medium $\mathrm{pH}$. According to the XRD data, irrespective of the synthesis method, diffractograms of $\mathrm{Fe}_{3} \mathrm{O}_{4} / \mathrm{SWCNT/PDPAC}$ identify reflection peaks of $\mathrm{Fe}_{3} \mathrm{O}_{4}$ in the range of scattering angles $2 \theta=46.1^{\circ}, 54.3^{\circ}, 66.8^{\circ}, 84.8^{\circ}, 91.2^{\circ}$, and $102.2^{\circ}(\mathrm{CrK} \alpha$ radiation) [43]. These diffraction peaks correlate to Miller indices (220), (311), (400), (422), (511), and (440), respectively, and refer to the cubic structure of $\mathrm{Fe}_{3} \mathrm{O}_{4}$ (JCPDS 19-0629) [50]. As can be seen in Figure 3, electron diffraction confirms the crystalline nature and phase composition of $\mathrm{Fe}_{3} \mathrm{O}_{4}$ nanoparticles. The diffraction rings correspond to $\mathrm{Fe}_{3} \mathrm{O}_{4}$ crystals. Since the single plane of SWCNT does not give a diffraction pattern, there is no carbon phase reflection peak at $2 \theta=39.8^{\circ}$. An amorphous halo in the range of scattering angles $2 \theta=20^{\circ}-43^{\circ}$ in the diffraction patterns of nanocomposites characterizes the polymer component (Figure $2 b$ ). The small wide diffraction peaks in the range of $2 \theta=20^{\circ}-43^{\circ}$ characterize the crystalline DPAC oligomers contained in the polymer fraction of nanomaterials obtained in the acidic medium (Figure 2c), which is also confirmed by the DSC data. Removal of the crystalline low molecular weight fraction by washing nanocomposites with acetone can lead to a dedoping of the polymer component. 

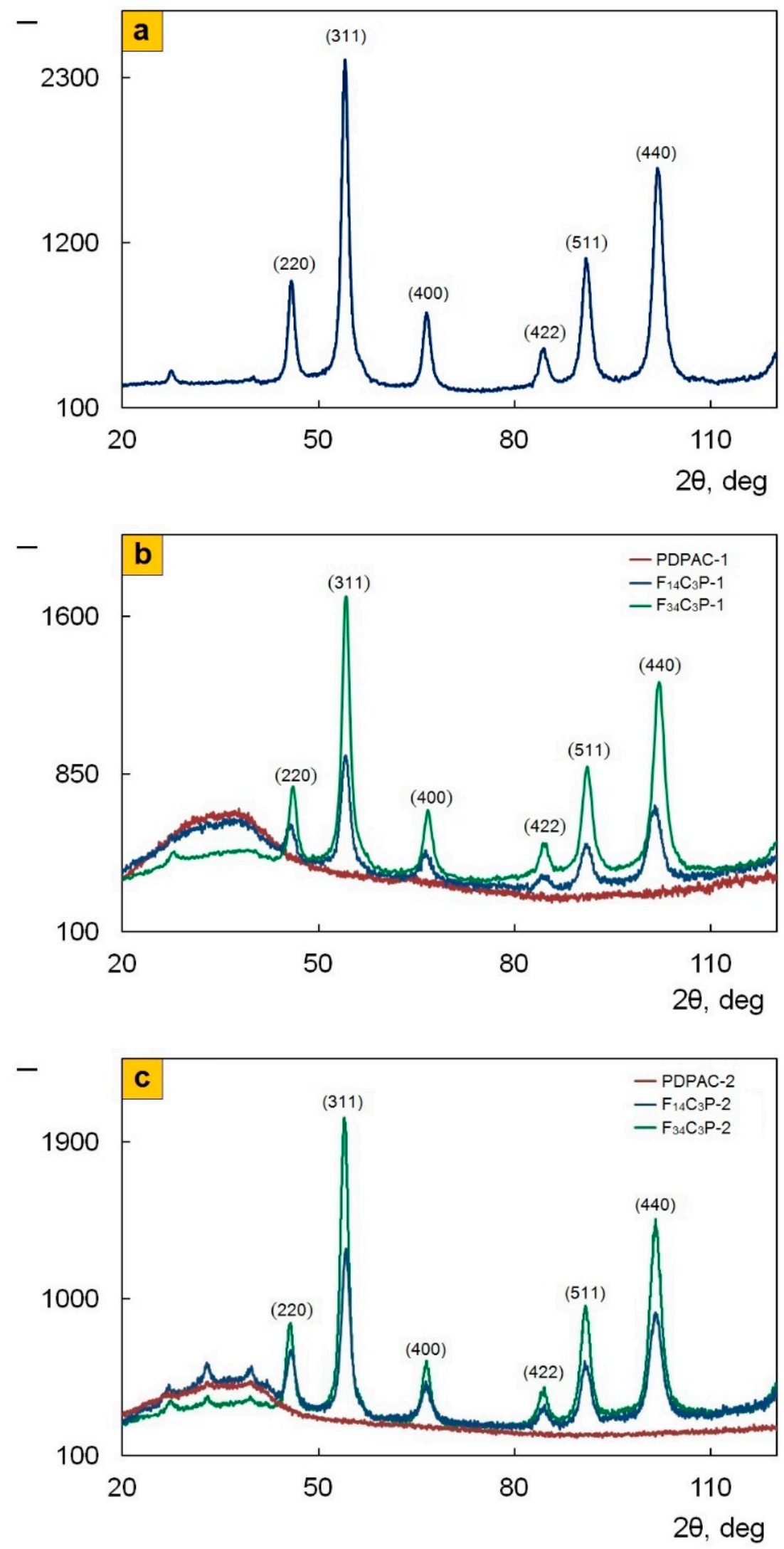

Figure 2. X-ray diffractograms of $\mathrm{Fe}_{3} \mathrm{O}_{4} / \mathrm{SWCNT}$ (a), PDPAC, and $\mathrm{Fe}_{3} \mathrm{O}_{4} / \mathrm{SWCNT} / \mathrm{PDPAC}$, prepared in alkaline (b) and acidic media (c). 

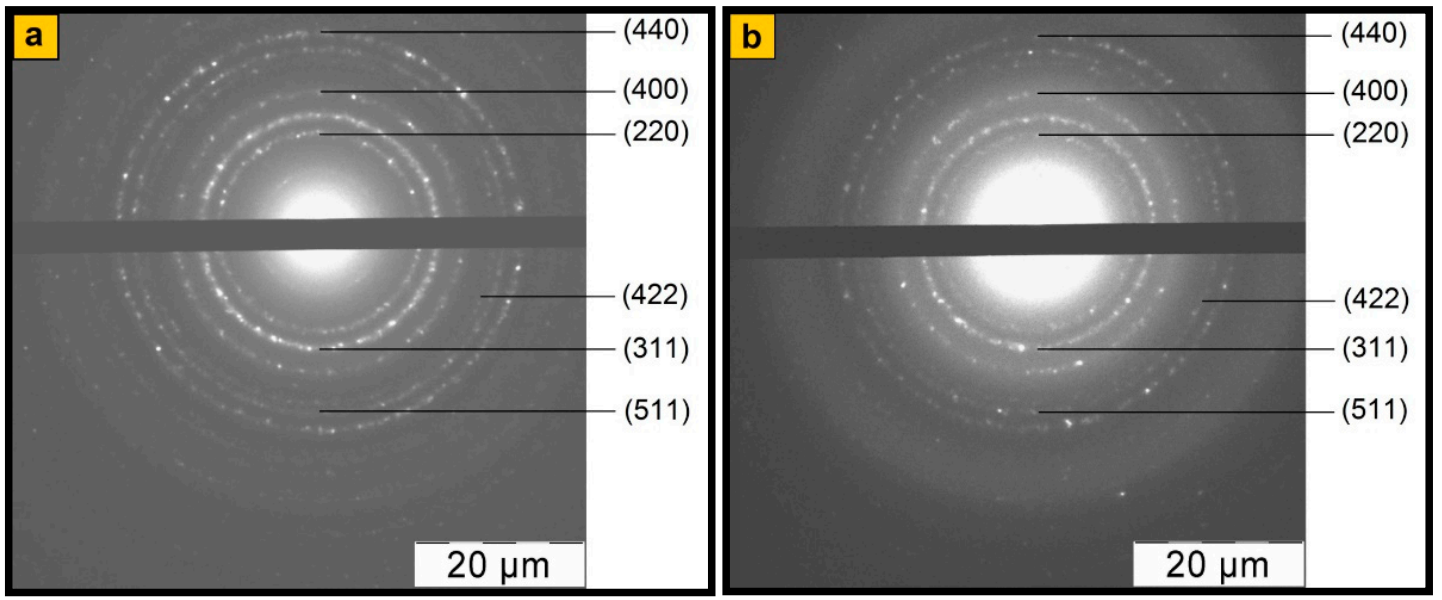

Figure 3. $\mathrm{Fe}_{3} \mathrm{O}_{4}$ diffraction images of $\mathrm{Fe}_{3} \mathrm{O}_{4} / \mathrm{SWCNT} / \mathrm{PDPAC}$, prepared in alkaline (a) and acidic media (b).

Table 2 demonstrates the volume fraction of materials. The fraction of amorphous and crystalline phases was calculated from the ratio of the areas of reflection peaks of the corresponding phases using standard samples. This technique is described in detail in [51]. As can be seen, the volume fraction of the crystalline low molecular weight fraction is negligible. Volume fraction of $\mathrm{Fe}_{3} \mathrm{O}_{4}$ in the nanocomposites reaches $62-95 \%$.

Table 2. Volume fraction of materials.

\begin{tabular}{cccc}
\hline \multirow{2}{*}{ Materials } & \multicolumn{3}{c}{ Volume Fraction, \% } \\
\cline { 2 - 4 } & $\begin{array}{c}\text { Amorphous } \\
\text { Polymer }\end{array}$ & $\begin{array}{c}\text { Crystalline } \\
\text { Polymer }\end{array}$ & $\mathbf{F e}_{3} \mathbf{O}_{4}$ \\
\hline PDPAC-1 & 100.00 & - & - \\
\hline $\mathrm{F}_{14} \mathrm{C}_{3} \mathrm{P}-1$ & 37.69 & - & 62.31 \\
$\mathrm{~F}_{34} \mathrm{C}_{3} \mathrm{P}-1$ & 5.24 & - & 94.76 \\
$\mathrm{~F}_{34} \mathrm{C}_{3}$ & - & - & 100.00 \\
$\mathrm{PDPAC}-2$ & 95.60 & 4.40 & - \\
\hline $\mathrm{F}_{14} \mathrm{C}_{3} \mathrm{P}-2$ & 28.99 & 2.35 & 68.66 \\
$\mathrm{~F}_{34} \mathrm{C}_{3} \mathrm{P}-2$ & 6.21 & 0.75 & 93.05 \\
\hline & & $* \mathrm{Fe}_{3} \mathrm{O}_{4} / \mathrm{SWCNT}$.
\end{tabular}

We have previously shown that, during the hydrolysis of iron (II) and (III) salts mixture in the solution of ammonium hydroxide in the presence of SWCNT, the synthesis of $\mathrm{Fe}_{3} \mathrm{O}_{4}$ nanoparticles and their immobilization on the surface of SWCNT with the formation of the metal-carbon $\mathrm{Fe}_{3} \mathrm{O}_{4} / \mathrm{SWCNT}$ nanocomposite occur simultaneously [43]. The XRD, TEM, and SEM data confirm the formation of $\mathrm{Fe}_{3} \mathrm{O}_{4} / \mathrm{SWCNT}$ (Figure 2a, Figure 4a, and Figure 5a). According to the FTIR data, during the $\mathrm{Fe}_{3} \mathrm{O}_{4} / \mathrm{SWCNT/PDPAC}-1$ synthesis in the interfacial process in an alkaline medium, the polymer interacts with the $\mathrm{Fe}_{3} \mathrm{O}_{4} / \mathrm{SWCNT}$ surface by binding the carboxylate ion and iron to form the Fe-OOC bond. The FTIR spectra of $\mathrm{Fe}_{3} \mathrm{O}_{4} / \mathrm{SWCNT/PDPAC}-1$ nanomaterials (Figure 6a) show a hypsochromic shift of the absorption band at 561 to $578 \mathrm{~cm}^{-1}$, which corresponds to stretching vibrations of the $v_{\mathrm{Fe}-\mathrm{O}}$ bond. The intensity of this band grows with the increase of $\mathrm{Fe}_{3} \mathrm{O}_{4}$ in the $\mathrm{Fe}_{3} \mathrm{O}_{4} /$ SWCNT/PDPAC- 1 nanocomposites. There is also a long-wavelength shift in the absorption band of the stretching vibrations of $v_{\mathrm{C}=\mathrm{O}}$ bonds in the carboxyl group to $1672 \mathrm{~cm}^{-1}$ compared to the location of this band in the polymer at $1682 \mathrm{~cm}^{-1}$ (Figure 7a). 

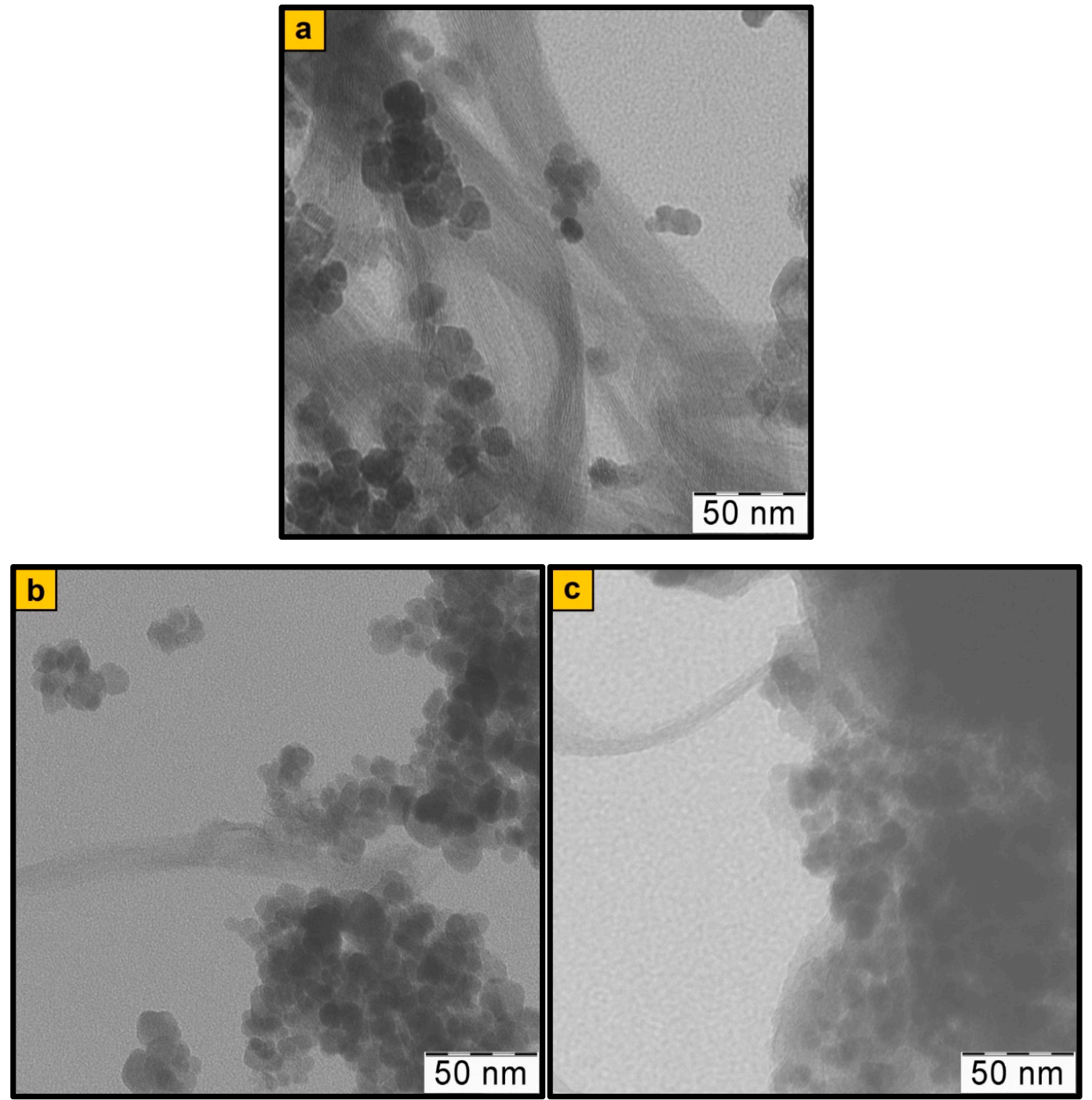

Figure 4. TEM images of $\mathrm{Fe}_{3} \mathrm{O}_{4} / \mathrm{SWCNT}$ (a) and $\mathrm{Fe}_{3} \mathrm{O}_{4} / \mathrm{SWCNT} / \mathrm{PDPAC}$, prepared in alkaline (b) and acidic media (c). 

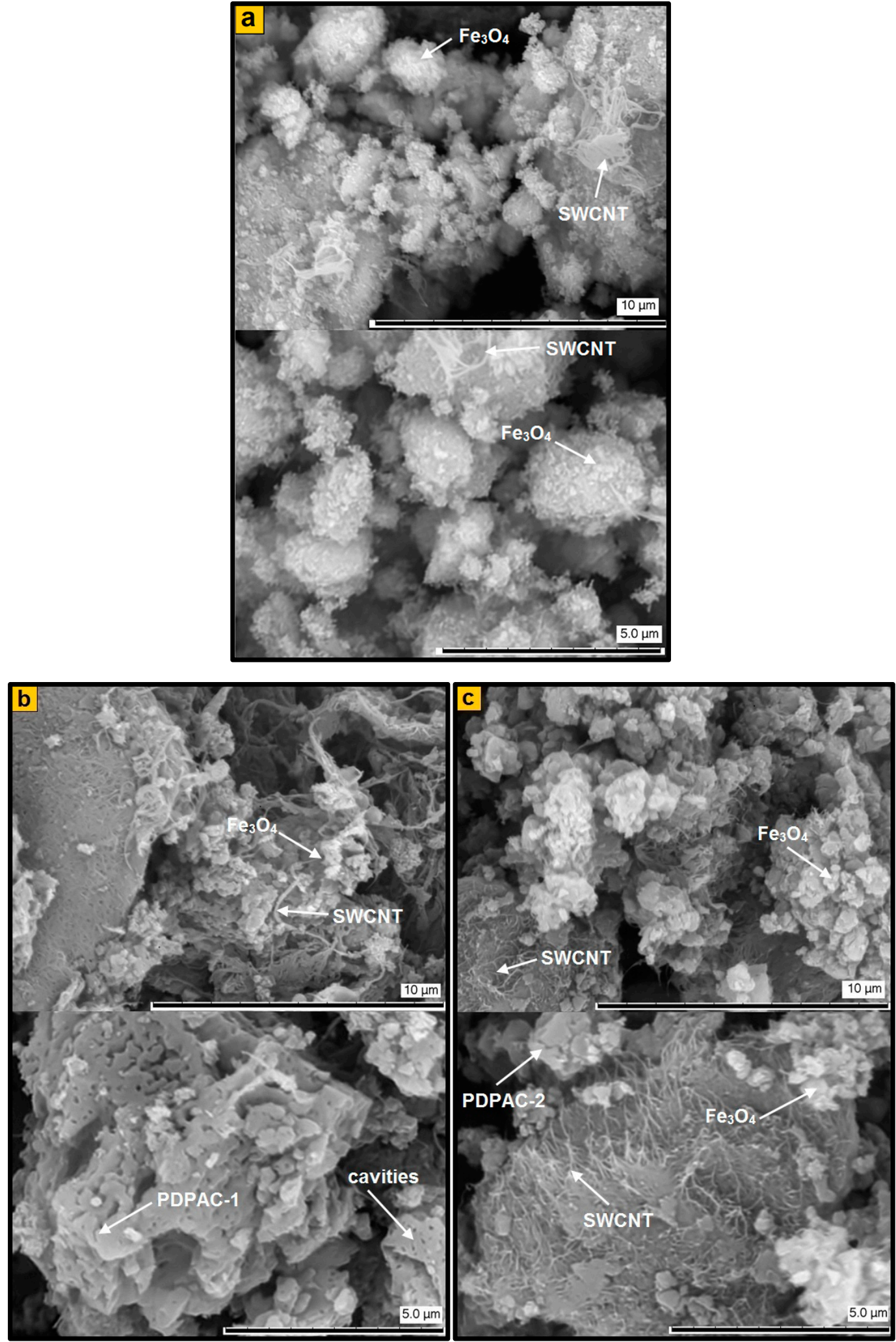

Figure 5. SEM images of $\mathrm{Fe}_{3} \mathrm{O}_{4} / \mathrm{SWCNT}$ (a) and $\mathrm{Fe}_{3} \mathrm{O}_{4} / \mathrm{SWCNT} / \mathrm{PDPAC}$, prepared in alkaline (b) and acidic media (c). 

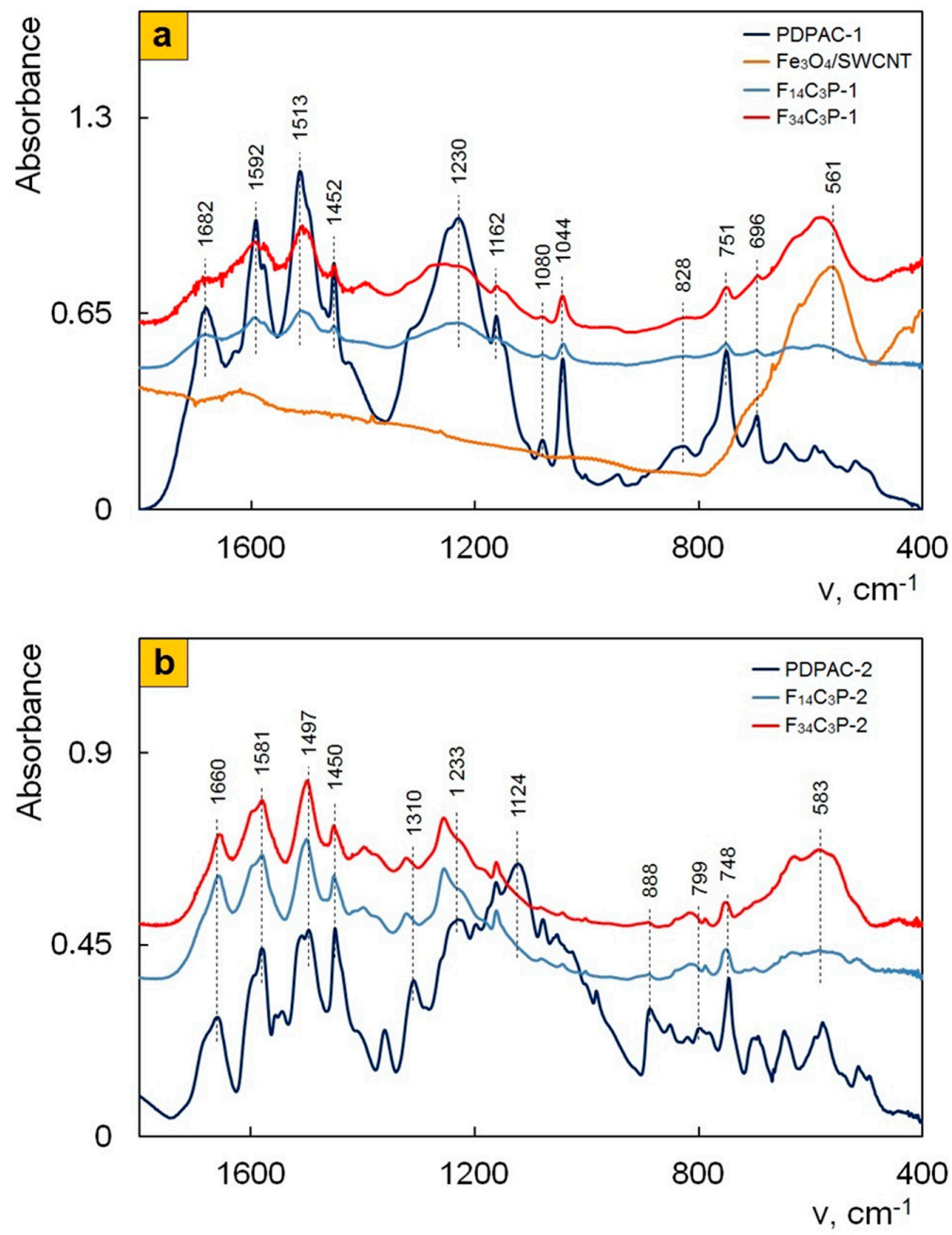

Figure 6. FTIR spectra of PDPAC, $\mathrm{Fe}_{3} \mathrm{O}_{4} / \mathrm{SWCNT}$, and $\mathrm{Fe}_{3} \mathrm{O}_{4} / \mathrm{SWCNT} / \mathrm{PDPAC}$, prepared in alkaline (a) and acidic media (b).

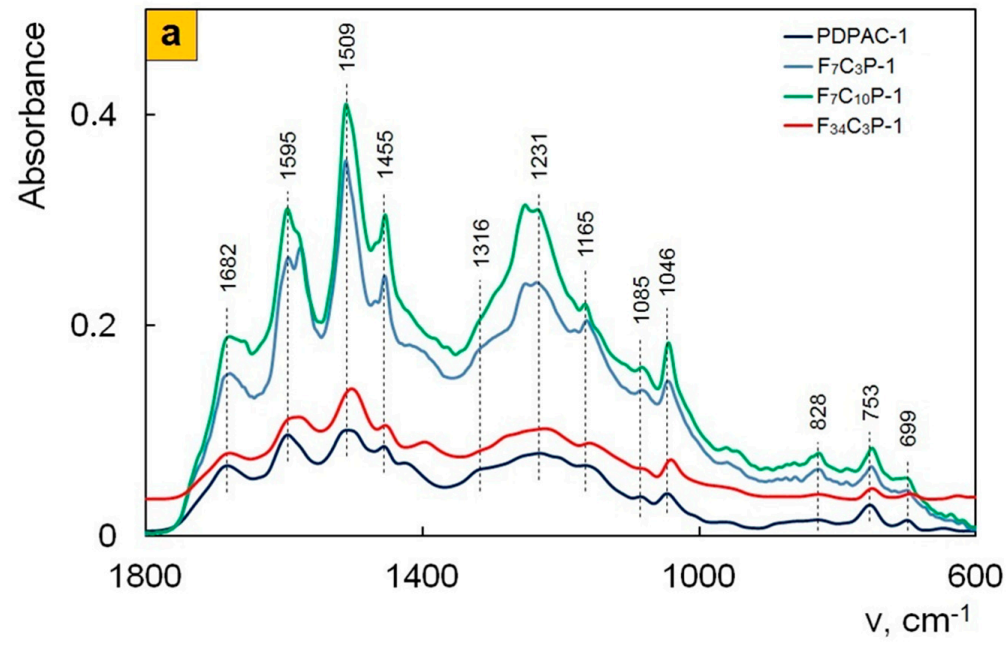

Figure 7. Cont. 


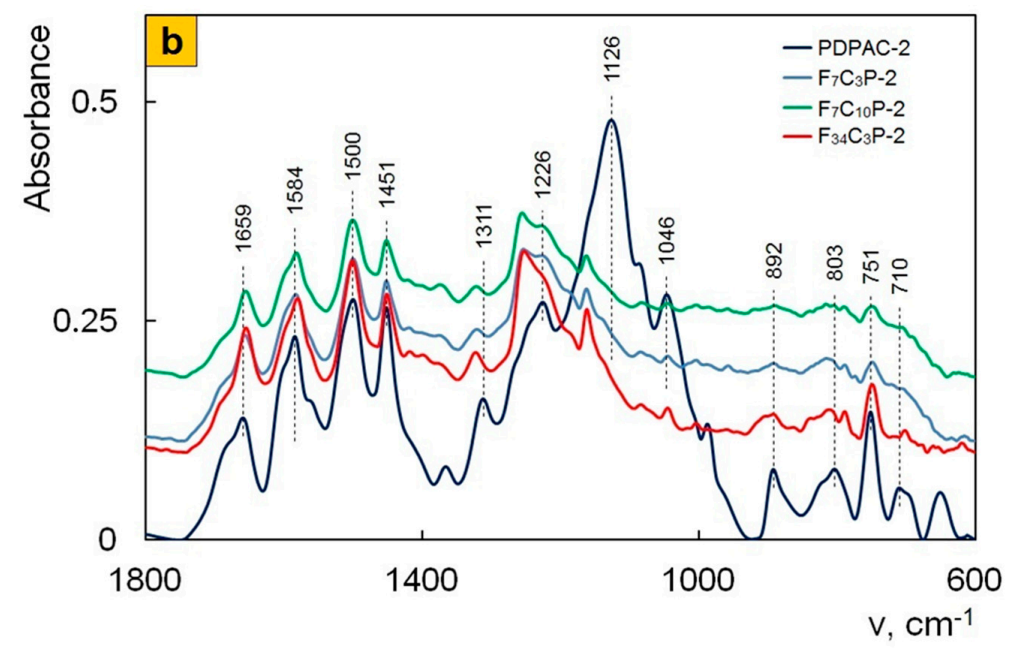

Figure 7. Attenuated total reflection (ATR) FTIR spectra of PDPAC and $\mathrm{Fe}_{3} \mathrm{O}_{4} / \mathrm{SWCNT} / \mathrm{PDPAC}$, prepared in alkaline (a) and acidic media (b).

It is shown that the size and shape of $\mathrm{Fe}_{3} \mathrm{O}_{4}$ nanoparticles do not depend on the $\mathrm{pH}$ of the synthesis reaction medium as well. Spherical $\mathrm{Fe}_{3} \mathrm{O}_{4}$ nanoparticles are clearly visible in TEM and SEM images of the $\mathrm{Fe}_{3} \mathrm{O}_{4} / \mathrm{SWCNT} / \mathrm{PDPAC}$ nanocomposites (Figures 4 and 5). However, the presence of an organic solvent (chloroform) in an alkaline medium leads to the formation of a polymer morphology with distinct cavities (Figure 5b). These cavities appear in places of chloroform droplets during the precipitation of the $\mathrm{Fe}_{3} \mathrm{O}_{4} / \mathrm{SWCNT} / \mathrm{PDPAC}-1$ nanocomposites in a sulfuric acid solution. According to the TEM data, the size of $\mathrm{Fe}_{3} \mathrm{O}_{4}$ nanoparticles in the nanomaterials is within the range of $2<d<14 \mathrm{~nm}$ irrespective of the obtaining method (Figure 4). The size distribution of coherent scattering regions in the $\mathrm{Fe}_{3} \mathrm{O}_{4}$ nanoparticles was calculated using the XRD data (Figure 8). In the $\mathrm{Fe}_{3} \mathrm{O}_{4} / \mathrm{SWCNT} / \mathrm{PDPAC}$ nanocomposites, about $80-90 \%$ of $\mathrm{Fe}_{3} \mathrm{O}_{4}$ crystallites are up to $5 \mathrm{~nm}$ in size. According to the ICP-AES, depending on the synthesis conditions, the content of iron is $\mathrm{C}_{\mathrm{Fe}}=6.2-34.7 \%$. In the obtained ternary hybrid nanomaterials, the problem of agglomeration of nanocomposite components is solved by the fact that the polymer structure contains functional groups that interact both with magnetite nanoparticles and with carbon nanotubes, preventing their aggregation.

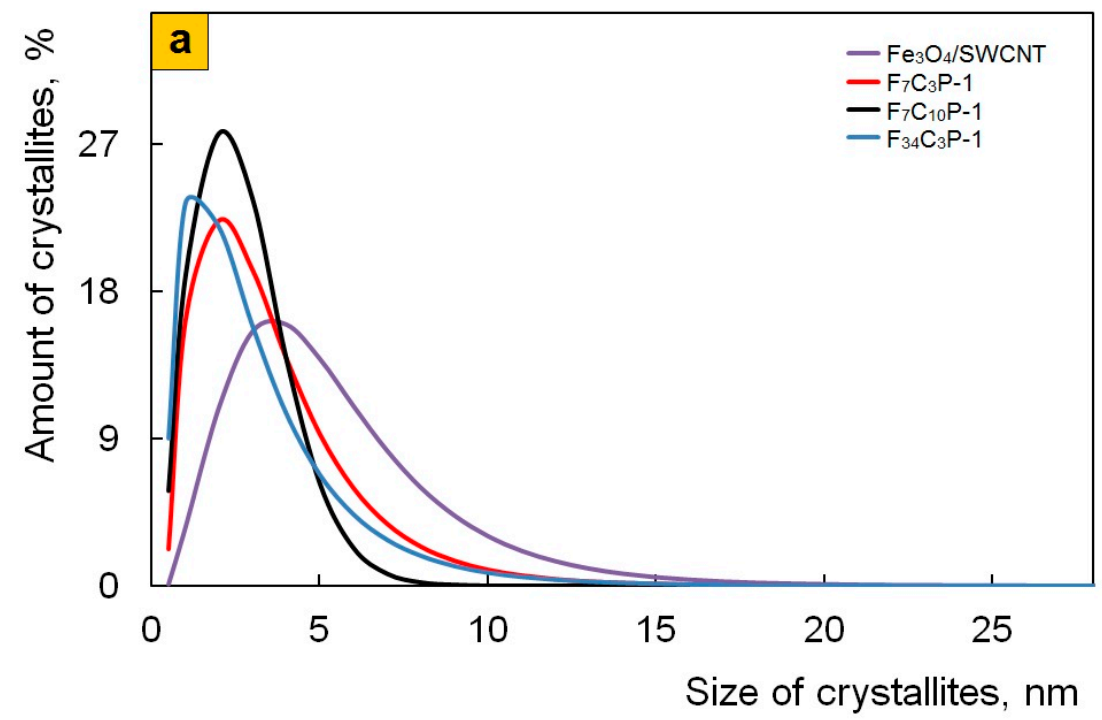

Figure 8. Cont. 


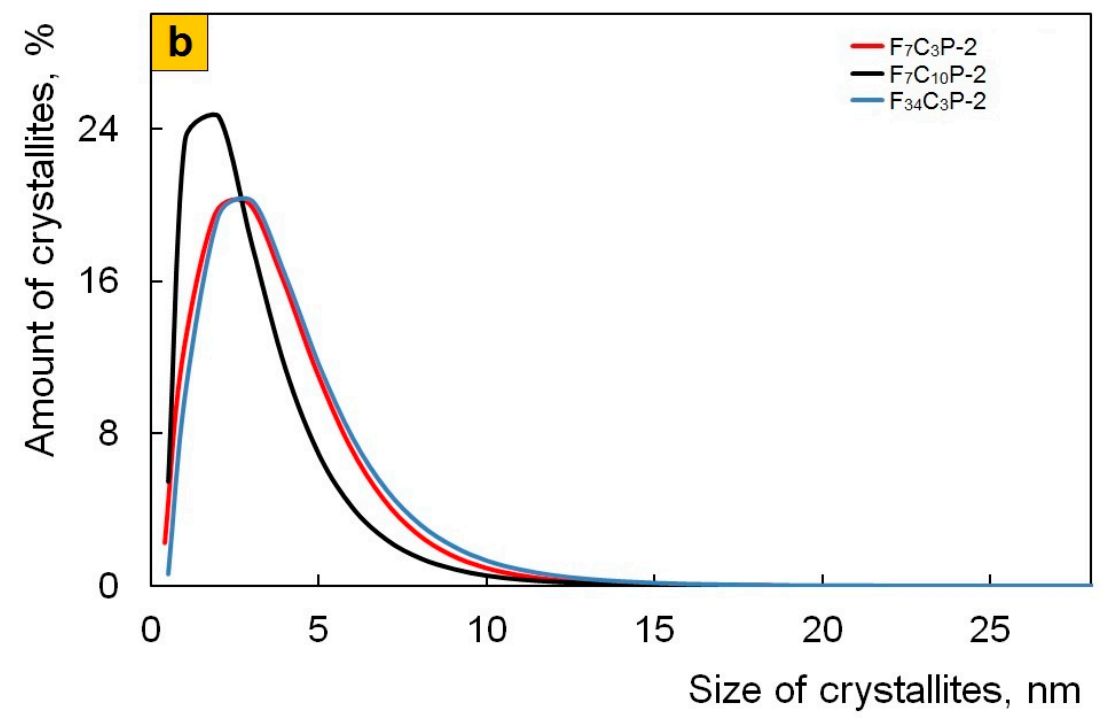

Figure 8. $\mathrm{Fe}_{3} \mathrm{O}_{4}$ crystallites size distribution in $\mathrm{Fe}_{3} \mathrm{O}_{4} / \mathrm{SWCNT}$ and $\mathrm{Fe}_{3} \mathrm{O}_{4} /$ SWCNT/PDPAC, prepared in alkaline (a) and acidic media (b).

Thus, regardless of the synthesis method, the $\mathrm{Fe}_{3} \mathrm{O}_{4} / \mathrm{SWCNT} / \mathrm{PDPAC}-1$ and $\mathrm{Fe}_{3} \mathrm{O}_{4} / \mathrm{SWCNT} /$ PDPAC-2 nanocomposites have the same phase composition: they contain PDPAC, carbon nanotubes, and $\mathrm{Fe}_{3} \mathrm{O}_{4}$ nanoparticles. However, the $\mathrm{Fe}_{3} \mathrm{O}_{4} / \mathrm{SWCNT/PDPAC}-1$ nanomaterials prepared in the interfacial process in an alkaline medium are metal-carbon $\mathrm{Fe}_{3} \mathrm{O}_{4} / \mathrm{SWCNT}$ nanocomposites coated with PDPAC-1, whereas the $\mathrm{Fe}_{3} \mathrm{O}_{4} / \mathrm{SWCNT} / \mathrm{PDPAC}-2$ nanocomposites obtained in an acidic medium are SWCNT dispersed in a polymer matrix with $\mathrm{Fe}_{3} \mathrm{O}_{4}$ nanoparticles immobilized on the SWCNT/PDPAC-2 surface (Figures 4 and 5).

Comparison of FTIR spectra of polymers and nanocomposites prepared under the same conditions (Figures 6 and 7) shows that all the main bands characterizing the chemical structure of PDPAC are retained in the FTIR spectra of $\mathrm{Fe}_{3} \mathrm{O}_{4} / \mathrm{SWCNT} / \mathrm{PDPAC}$ regardless of the obtaining method. As can be seen in Figures 6 and 7, the chemical structure of the polymer component depends strongly on the $\mathrm{pH}$ of the synthesis reaction medium. It was established that during the synthesis of $\mathrm{Fe}_{3} \mathrm{O}_{4} / \mathrm{SWCNT} / \mathrm{PDPAC}-1$ nanocomposites in an alkaline medium ( $\mathrm{pH}$ 11.4), the polymer chain grows via the $\mathrm{C}-\mathrm{C}$ bonding of phenyl rings in 2- and 4-positions in relation to nitrogen $\left(\delta_{\mathrm{C}-\mathrm{H}}=828\right.$ and $\left.753 \mathrm{~cm}^{-1}\right)$. This differs significantly from the type of $\mathrm{C}-\mathrm{C}$ bonding that takes place during the synthesis of $\mathrm{Fe}_{3} \mathrm{O}_{4} / \mathrm{SWCNT/PDPAC}-2$ nanocomposites in an acidic medium ( $\mathrm{pH} 0.3$ ), when the polymer chain grows via the $\mathrm{C}-\mathrm{C}$ bonding of phenyl rings in the para position relative to nitrogen $\left(\delta_{\mathrm{C}-\mathrm{H}}=892\right.$ and $803 \mathrm{~cm}^{-1}$ ). The chemical structure of the corresponding polymer components is shown in Figure 1 . This dependence of the polymer matrix chemical structure on the reaction medium $\mathrm{pH}$ was observed during the synthesis of SWCNT/PDPAC nanocomposites in the absence of $\mathrm{Fe}_{3} \mathrm{O}_{4}$ nanoparticles [52].

As the content of carbon nanotubes increases, ATR FTIR spectra of $\mathrm{Fe}_{3} \mathrm{O}_{4} /$ SWCNT/PDPAC-1 nanocomposites (Figure 7a) demonstrate a bathochromic shift in the PDPAC-1 skeletal vibration frequencies at $10-16 \mathrm{~cm}^{-1}$, which indicates the $\pi-\pi^{*}$ interaction of aromatic units of the polymer with the $\mathrm{Fe}_{3} \mathrm{O}_{4} / \mathrm{SWCNT}$ surface in an alkaline medium (stacking effect). The polymer formation on the $\mathrm{Fe}_{3} \mathrm{O}_{4} / \mathrm{CNT}$ surface provides the charge transfer, which is manifested in the shift of skeletal oscillation frequencies of the polymer [53-55].

As the content of carbon nanotubes grows, the FTIR spectra of $\mathrm{Fe}_{3} \mathrm{O}_{4} / \mathrm{SWCNT/PDPAC}-2$ nanocomposites show the shift of absorption bands at 1659 and $1226 \mathrm{~cm}^{-1}$, associated with stretching vibrations of $v_{\mathrm{C}=\mathrm{O}}$ in $\mathrm{COOH}$ groups, as well as the shift of the band at 561 to $583 \mathrm{~cm}^{-1}$, corresponding to stretching vibrations of the $v_{\mathrm{Fe}-\mathrm{O}}$ bond (Figures 6 and 7). This indicates the interaction of carboxyl groups of SWCNT/PDPAC-2 with $\mathrm{Fe}_{3} \mathrm{O}_{4}$. 


\subsection{Electrical Characterization of Nanomaterials}

Frequency dependence on the AC conductivity of $\mathrm{Fe}_{3} \mathrm{O}_{4} / \mathrm{SWCNT} / \mathrm{PDPAC}$ nanocomposites was studied in the frequency range of $0.1 \mathrm{~Hz}-1.0 \mathrm{MHz}$ (Figure 9). According to [56-58], the frequency dependence on the conductivity $\left(\sigma_{\mathrm{ac}}\right)$ is described by evaluation:

$$
\sigma_{\mathrm{ac}}=\sigma_{\mathrm{dc}}+A \omega^{n}
$$

where $\omega=2 \pi \mathrm{f}$ is the angular frequency,

$\sigma_{\mathrm{dc}}$-the frequency independent (dc) part of conductivity,

$n$-the exponential parameter $(0 \leq \mathrm{n} \leq 1)$,

$A$ - the thermally activated quantity.

$A$ and $n$ depend on the temperature and the volume fraction of the conducting component.
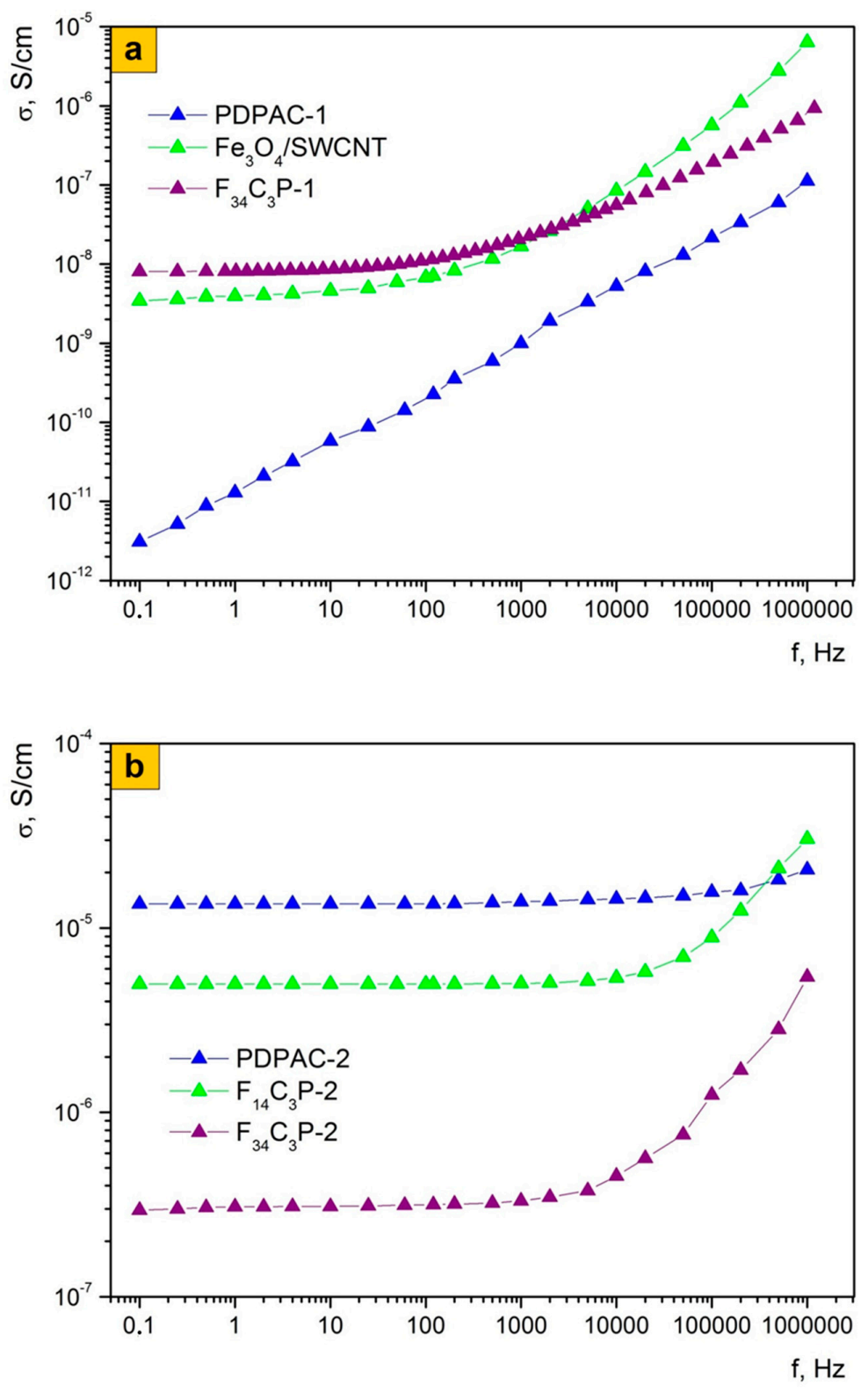

Figure 9. Cont. 


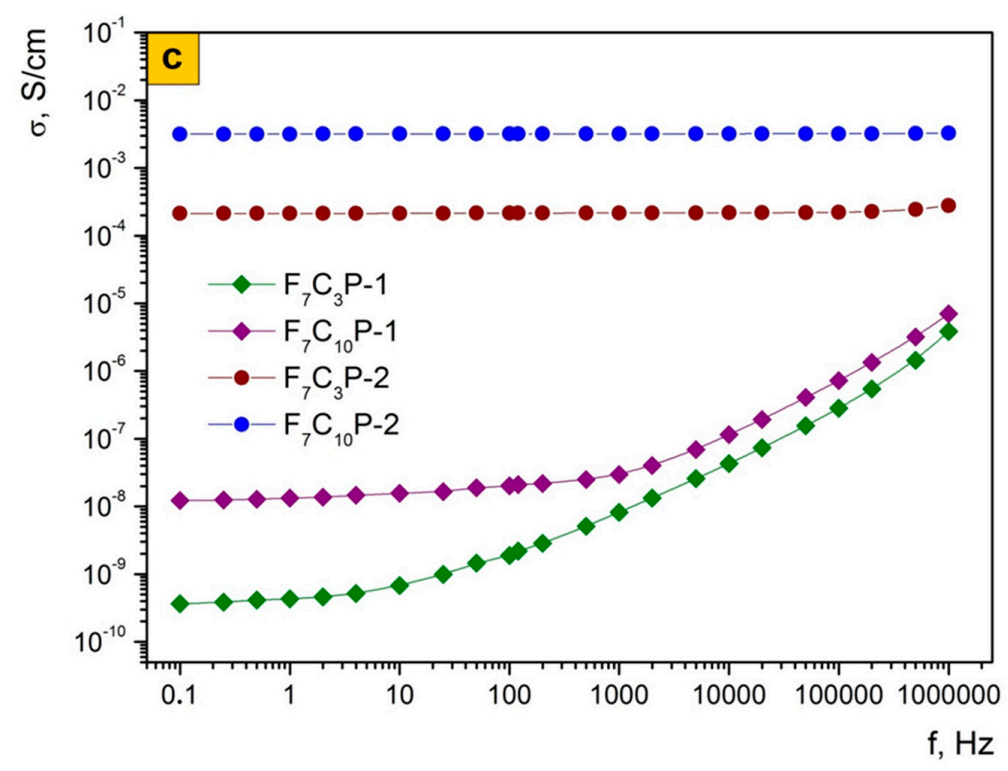

Figure 9. Frequency dependence of the conductivity for PDPAC, $\mathrm{Fe}_{3} \mathrm{O}_{4} / \mathrm{SWCNT}$, and $\mathrm{Fe}_{3} \mathrm{O}_{4} /$ SWCNT/PDPAC, prepared in alkaline $(\mathbf{a}, \mathbf{c})$ and acidic media $(\mathbf{b}, \mathbf{c})$.

Table 3 lists the conductivity values of materials. It can be seen that the conductivity $\left(\sigma_{\mathrm{ac}}\right)$ of nanocomposites depends on the $\mathrm{pH}$ of the synthesis reaction medium.

Table 3. The conductivity values of materials.

\begin{tabular}{cccccc}
\hline Materials & \multicolumn{2}{c}{${ }^{*} \sigma_{\mathrm{ac}}, \mathrm{S} / \mathrm{cm}$} & $\sigma_{\mathrm{dc}}, \mathrm{S} / \mathrm{cm}$ & $\mathbf{n}$ & $\mathbf{A}$ \\
\hline PDPAC-1 & $3.1 \times 10^{-12}$ & $1.1 \times 10^{-7}$ & $2.8 \times 10^{-12}$ & 0.75 & $8.5 \times 10^{-12}$ \\
\hline $\mathrm{F}_{7} \mathrm{C}_{3} \mathrm{P}-1$ & $3.6 \times 10^{-10}$ & $1.2 \times 10^{-7}$ & $2.4 \times 10^{-10}$ & 0.82 & $1.7 \times 10^{-13}$ \\
$\mathrm{~F}_{7} \mathrm{C}_{10} \mathrm{P}-1$ & $1.2 \times 10^{-8}$ & $9.6 \times 10^{-7}$ & $1.1 \times 10^{-8}$ & 0.96 & $1.9 \times 10^{-12}$ \\
$\mathrm{~F}_{34} \mathrm{C}_{3} \mathrm{P}-1$ & $8.1 \times 10^{-9}$ & $8.7 \times 10^{-7}$ & $6.8 \times 10^{-9}$ & 0.99 & $5.4 \times 10^{-13}$ \\
$\mathrm{~F}_{34} \mathrm{C}_{3}{ }^{* *}$ & $3.5 \times 10^{-9}$ & $2.5 \times 10^{-6}$ & $2.3 \times 10^{-9}$ & 1.00 & $9.7 \times 10^{-13}$ \\
\hline $\mathrm{PDPAC} \mathrm{P}$ & $1.4 \times 10^{-5}$ & $2.2 \times 10^{-5}$ & $1.0 \times 10^{-5}$ & 0.45 & $6.9 \times 10^{-9}$ \\
\hline $\mathrm{F}_{7} \mathrm{C}_{3} \mathrm{P}-2$ & $2.5 \times 10^{-4}$ & $2.7 \times 10^{-4}$ & $2.1 \times 10^{-4}$ & 0.31 & $3.0 \times 10^{-7}$ \\
$\mathrm{~F}_{7} \mathrm{C}_{10} \mathrm{P}-2$ & $3.7 \times 10^{-3}$ & $3.3 \times 10^{-3}$ & $3.2 \times 10^{-3}$ & 0.51 & $2.0 \times 10^{-8}$ \\
$\mathrm{~F}_{14} \mathrm{C}_{3} \mathrm{P}-2$ & $4.6 \times 10^{-6}$ & $3.1 \times 10^{-5}$ & $4.3 \times 10^{-6}$ & 0.64 & $9.0 \times 10^{-11}$ \\
$\mathrm{~F}_{34} \mathrm{C}_{3} \mathrm{P}-2$ & $3.4 \times 10^{-7}$ & $3.6 \times 10^{-6}$ & $3.1 \times 10^{-7}$ & 0.74 & $1.3 \times 10^{-9}$ \\
\hline
\end{tabular}

${ }^{*} \sigma$-The AC conductivity at $0.1 \mathrm{~Hz}$ and $1.0 \mathrm{MHz} .{ }^{* *} \mathrm{Fe}_{3} \mathrm{O}_{4} / \mathrm{SWCNT}$.

At low frequencies, the $\mathrm{Fe}_{3} \mathrm{O}_{4} / \mathrm{SWCNT/PDPAC}-1$ nanocomposites as well as $\mathrm{Fe}_{3} \mathrm{O}_{4} / \mathrm{SWCNT}$ are characterized by weak frequency dependence on electrical conductivity. At the same time, the electrical conductivity of nanocomposites is several orders of magnitude higher than that of PDPAC-1 $\left(3.1 \times 10^{-12} \mathrm{~S} / \mathrm{cm}\right)$ and amounts to $3.5 \times 10^{-9} \mathrm{~S} / \mathrm{cm}\left(\mathrm{F}_{34} \mathrm{C}_{3}\right)$ and $8.1 \times 10^{-9} \mathrm{~S} / \mathrm{cm}\left(\mathrm{F}_{34} \mathrm{C}_{3} \mathrm{P}-1\right)$ at $0.1 \mathrm{~Hz}$ (Figure 9a). Apparently, the conductivity of $\mathrm{Fe}_{3} \mathrm{O}_{4} / \mathrm{SWCNT} / \mathrm{PDPAC}-1$ is contributed significantly by the metal-carbon $\mathrm{Fe}_{3} \mathrm{O}_{4} / \mathrm{SWCNT}$ nanocomposite, i.e., the increase in electrical conductivity of nanomaterials is due to the presence both of SWCNT and magnetite nanoparticles. As frequency grows, the electrical conductivity of $\mathrm{F}_{34} \mathrm{C}_{3} \mathrm{P}-1$ increases gradually by two orders of magnitude to $8.7 \times 10^{-7} \mathrm{~S} / \mathrm{cm}$.

The electrical conductivity of $\mathrm{Fe}_{3} \mathrm{O}_{4} / \mathrm{SWCNT/PDPAC}-2$ nanocomposites at low frequencies is significantly higher than the conductivity of $\mathrm{Fe}_{3} \mathrm{O}_{4} / \mathrm{SWCNT} / \mathrm{PDPAC}-1$. This is due to the doping of the polymer matrix that occurs during the synthesis of nanocomposites in an acidic medium. As can be seen in Figure 9b, the electrical conductivity of neat PDPAC-2 does not depend much on 
frequency and amounts to $(1.4-2.2) \times 10^{-5} \mathrm{~S} / \mathrm{cm}$. The $\mathrm{F}_{7} \mathrm{C}_{3} \mathrm{P}-2$ nanocomposite with a low magnetite content demonstrates an increase in its conductivity by an order of magnitude compared to PDPAC-2 up to $2.1 \times 10^{-4} \mathrm{~S} / \mathrm{cm}$. Conductivity of carbon nanotubes contributes to the growth in electrical conductivity as well. This also explains the fact that conductivity $\left(\sigma_{\mathrm{ac}}\right)$ does not depend on frequency at low magnetite content. However, with the increase of $\mathrm{Fe}_{3} \mathrm{O}_{4}$ content in the $\mathrm{F}_{14} \mathrm{C}_{3} \mathrm{P}-2$ and $\mathrm{F}_{34} \mathrm{C}_{3} \mathrm{P}-2$ nanocomposites, the electrical conductivity drops to $4.6 \times 10^{-6} \mathrm{~S} / \mathrm{cm}$ and $3.1 \times 10^{-7} \mathrm{~S} / \mathrm{cm}$, respectively. An important role in reducing the conductivity of nanocomposites belongs to the electrical conductivity of $\mathrm{Fe}_{3} \mathrm{O}_{4}$ that has a significantly lower conductivity $\left(\sim 10^{-10} \mathrm{~S} / \mathrm{cm}\right)$ compared to the doped polymer and CNT. At the same time, the frequency dependence on the electrical conductivity is observed. As frequency increases, the electrical conductivity of $\mathrm{F}_{14} \mathrm{C}_{3} \mathrm{P}-2$ and $\mathrm{F}_{34} \mathrm{C}_{3} \mathrm{P}-2$ rises to $3.1 \times 10^{-5} \mathrm{~S} / \mathrm{cm}$ and $3.6 \times 10^{-6} \mathrm{~S} / \mathrm{cm}$, respectively.

As can be seen in Figure 9c, the electrical conductivity of the nanocomposites depends on carbon nanotubes concentration. With the growth in SWCNT content from 3 to $10 \mathrm{wt}$. \%, the electrical conductivity of $\mathrm{Fe}_{3} \mathrm{O}_{4} / \mathrm{SWCNT/PDPAC}-1$ increases by two orders of magnitude from $3.6 \times 10^{-10} \mathrm{~S} / \mathrm{cm}\left(\mathrm{F}_{7} \mathrm{C}_{3} \mathrm{P}-1\right)$ to $1.2 \times 10^{-8} \mathrm{~S} / \mathrm{cm}\left(\mathrm{F}_{7} \mathrm{C}_{10} \mathrm{P}-1\right)$. At high frequencies, the electrical conductivity of $\mathrm{Fe}_{3} \mathrm{O}_{4} / \mathrm{SWCNT} / \mathrm{PDPAC}-1$ nanocomposites reaches $(1.2-9.6) \times 10^{-7} \mathrm{~S} / \mathrm{cm}$, depending on the content of SWCNT. With the increase in SWCNT content from 3 to $10 \mathrm{wt}$. \%, the conductivity of $\mathrm{Fe}_{3} \mathrm{O}_{4} / \mathrm{SWCNT} / \mathrm{PDPAC}-2$ rises from $2.1 \times 10^{-4} \mathrm{~S} / \mathrm{cm}\left(\mathrm{F}_{7} \mathrm{C}_{3} \mathrm{P}-2\right)$ to $3.2 \times 10^{-3} \mathrm{~S} / \mathrm{cm}\left(\mathrm{F}_{7} \mathrm{C}_{10} \mathrm{P}-2\right)$. The main contribution to the growth of electrical conductivity is made by carbon nanotubes, which is confirmed by the independence of the $\sigma_{\text {ac }}$ conductivity on frequency when $\mathrm{Fe}_{3} \mathrm{O}_{4}$ content is low.

Thus, as can be seen in Table 3, for all nanocomposites, the exponential parameter $n$ lies in the range of $0 \leq n \leq 1$, which is typical for disperse systems with a hopping mechanism of charge transfer $[43,56-60]$. Since the frequency dependence on the AC conductivity of nanocomposites shows an increase with the growth in current frequency, it can be argued that the effect of tunneling is minimal. At low frequencies, the DC conductivity plays an important role, the growth of which leads to a high frequency shift of the region of sharp increase in electrical conductivity.

\subsection{Thermal Properties of Nanomaterials}

TGA and DSC methods were used to study thermal stability of the nanocomposites depending on the preparation process. Figure 10 shows TGA thermograms of $\mathrm{Fe}_{3} \mathrm{O}_{4} / \mathrm{SWCNT} / \mathrm{PDPAC}$ compared to PDPAC at heating up to $1000{ }^{\circ} \mathrm{C}$ in argon flow and in air. Table 4 presents the main thermal properties of the materials. As can be seen, the weight loss curves of the obtained materials have a stepwise pattern. Weight loss at low temperatures is associated with moisture removal, which is also confirmed by the DSC data. Figure 11 shows DSC thermograms of $\mathrm{Fe}_{3} \mathrm{O}_{4} / \mathrm{SWCNT/PDPAC}$. There is an endothermic peak at $\sim 105^{\circ} \mathrm{C}$ on the DSC thermograms of nanocomposites. A small endothermic peak at $\sim 273{ }^{\circ} \mathrm{C}$ in the $\mathrm{Fe}_{3} \mathrm{O}_{4} / \mathrm{SWCNT} / \mathrm{PDPAC}-2$ is associated with the decomposition of low molecular weight oligomers. When re-heated, this peak is absent. X-ray diffraction data also confirm the content of the crystalline low molecular weight fraction $(0.75-2.35 \%)$ in the nanocomposites obtained in an acidic medium (Figure 2c, Table 2).

Table 4. Thermal properties of materials.

\begin{tabular}{lcccc}
\hline Materials & ${ }^{*} \boldsymbol{T}_{\mathbf{5} \%},{ }^{\circ} \mathbf{C}$ & ${ }^{* *} \boldsymbol{T}_{\mathbf{2 5} \%},{ }^{\circ} \mathbf{C}$ & ${ }^{* * *} \boldsymbol{T}_{\mathbf{5 0} \%},{ }^{\circ} \mathbf{C}$ & ${ }^{* * * *}$ Residue, $\%$ \\
\hline PDPAC-1 & $182 / 205$ & $400 / 324$ & $522 / 663$ & $0 / 19$ \\
PDPAC-2 & $104 / 102$ & $232 / 243$ & $517 / 396$ & $0 / 35$ \\
$\mathrm{~F}_{34} \mathrm{C}_{3} \mathrm{P}-1$ & $238 / 201$ & $403 / 628$ & $>1000 / 910$ & $53 / 48$ \\
$\mathrm{~F}_{34} \mathrm{C}_{3} \mathrm{P}-2$ & $180 / 225$ & $388 / 677$ & $542 />1000$ & $48 / 52$ \\
\hline${ }^{*} T_{5 \%},{ }^{* *} T_{25 \%},{ }^{* * *} T_{50 \%}-5,25$ and $50 \%$ weight losses (air/argon), ${ }^{* * * *}$ residue at $1000{ }^{\circ} \mathrm{C}$ (air/argon).
\end{tabular}



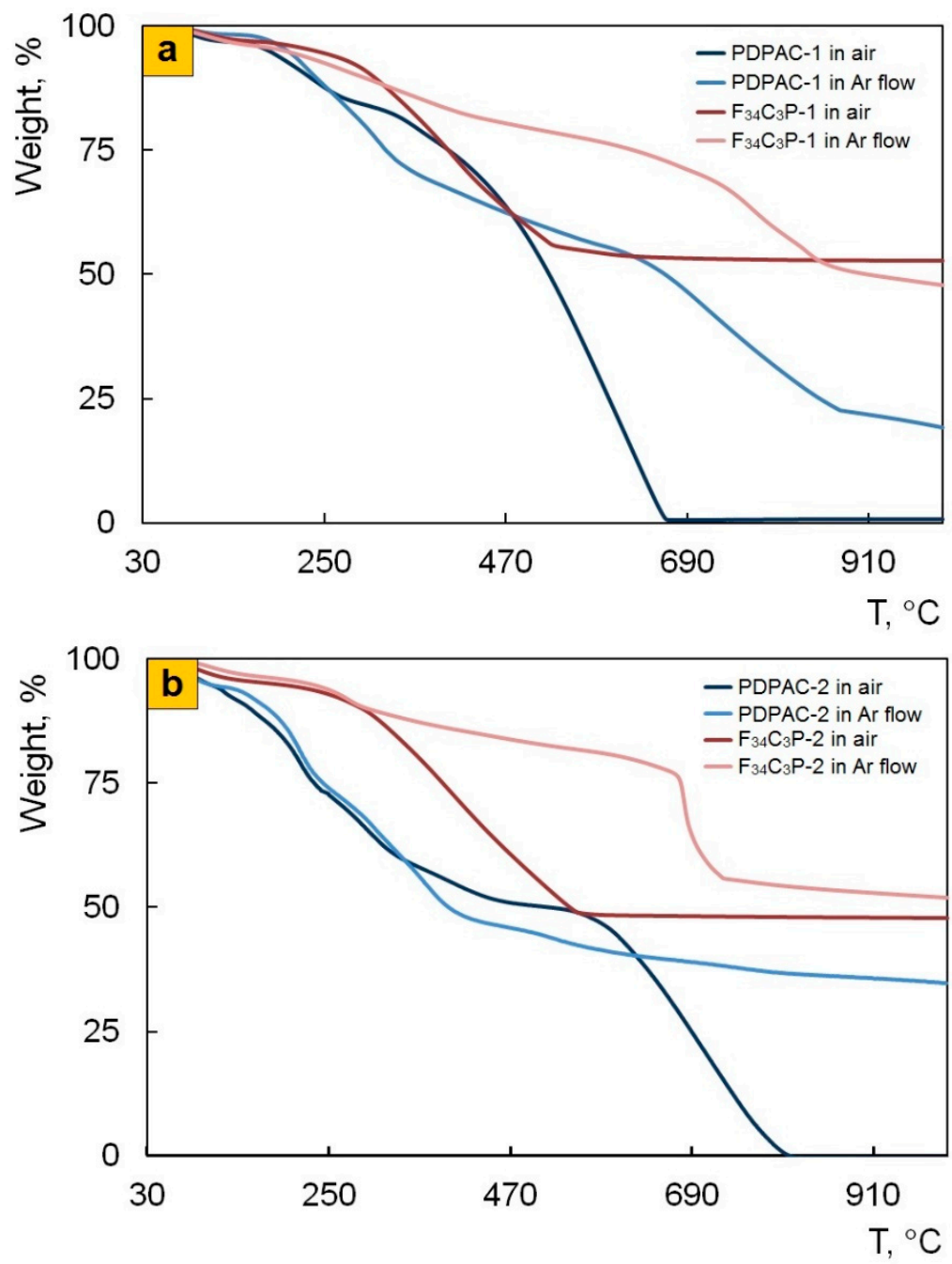

Figure 10. TGA thermograms of PDPAC and $\mathrm{Fe}_{3} \mathrm{O}_{4} / \mathrm{SWCNT} / \mathrm{PDPAC}$, prepared in alkaline (a) and acidic media (b), at heating up to $1000^{\circ} \mathrm{C}$ in the argon flow and in air.

As seen in Figure 10, both in the PDPAC-1 and PDPAC-2 polymers, the weight loss at $\sim 170{ }^{\circ} \mathrm{C}$ is connected with the removal of $\mathrm{COOH}$ groups [52]. In this temperature range, the DSC thermograms of polymers have an exothermic peak associated with decomposition $[44,46]$. The absence of weight loss in the $\mathrm{Fe}_{3} \mathrm{O}_{4} / \mathrm{SWCNT/PDPAC}$ nanomaterials in this temperature range is explained by the fact that the carboxylate groups of the polymer interact with either the $\mathrm{Fe}_{3} \mathrm{O}_{4}$ nanoparticles or the aromatic structures of SWCNT, depending on the method of nanocomposites preparation. The DSC thermograms of nanomaterials presented in Figure 11 do not show thermal effects in this temperature range.

The resulting nanomaterials are characterized by high thermal stability that exceeds the thermal stability of PDPAC significantly. Regardless of the preparation method, the $\mathrm{Fe}_{3} \mathrm{O}_{4} / \mathrm{SWCNT/PDPAC}$ nanocomposites lose half of their initial weight in an inert atmosphere at temperatures above $900{ }^{\circ} \mathrm{C}$. At $1000{ }^{\circ} \mathrm{C}$, both in an inert atmosphere and in air, the residue is $\sim 50 \%$ (Table 4 ). 

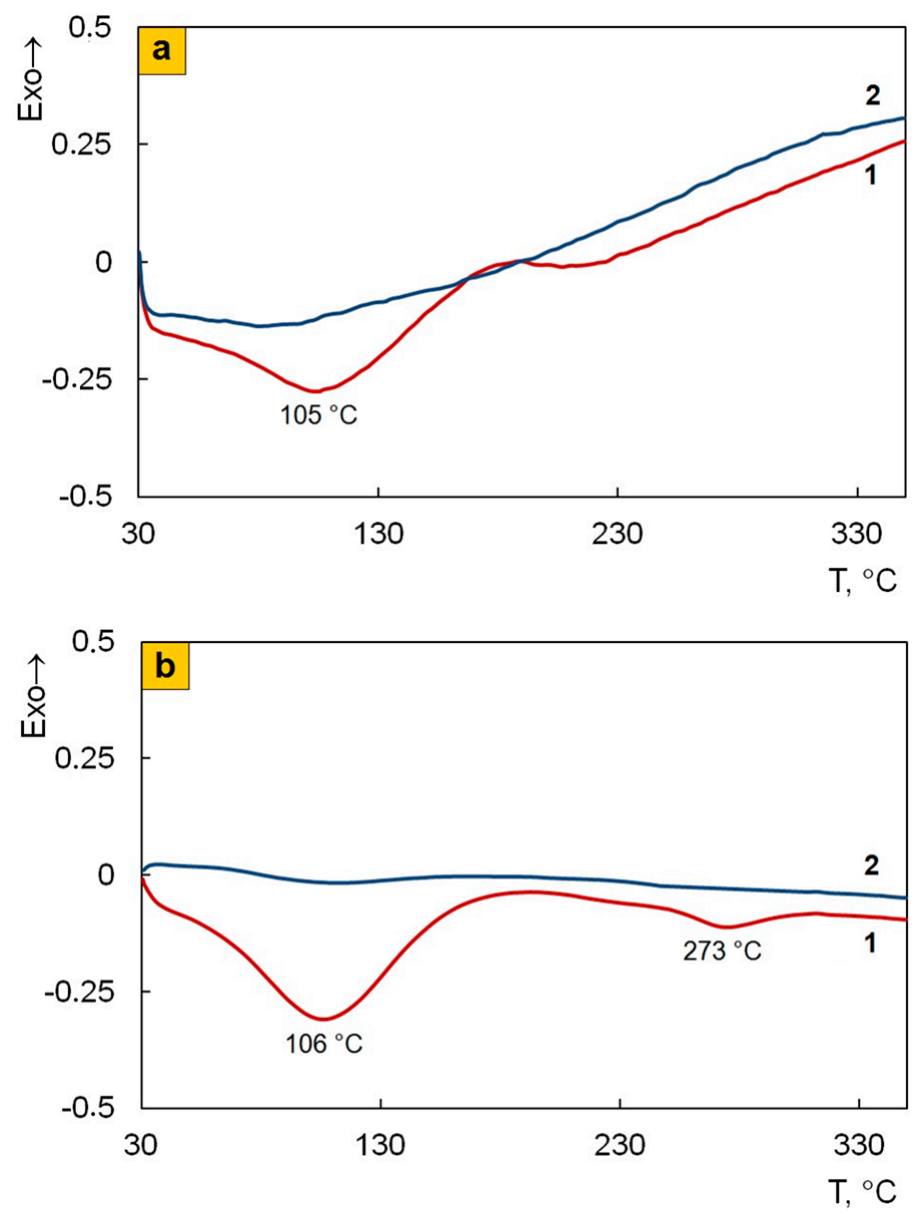

Figure 11. DSC thermograms of $\mathrm{Fe}_{3} \mathrm{O}_{4} / \mathrm{SWCNT} / \mathrm{PDPAC}$, prepared in alkaline (a) and acidic media (b), at heating in the nitrogen flow to $350^{\circ} \mathrm{C}$ (1-first heating, 2-second heating).

\subsection{Magnetic Properties of Nanomaterials}

Magnetic properties of $\mathrm{Fe}_{3} \mathrm{O}_{4} / \mathrm{SWCNT/PDPAC}$ nanomaterials were studied and the values of their main magnetic parameters were measured. The dependence of the magnetization on the magnitude of the applied magnetic field at room temperature is shown in Figure 12. Table 5 lists the values of the main magnetic properties of nanocomposites.

Table 5. Magnetic properties of nanomaterials.

\begin{tabular}{|c|c|c|c|c|c|}
\hline Nanomaterials & $\mathrm{Fe}, \%$ * & $\mathrm{H}_{C}, \mathrm{Oe}$ & $M_{S}, \mathrm{emu} / \mathrm{g}$ & $M_{R}, \mathrm{emu} / \mathrm{g}$ & $M_{R} / M_{S}$ \\
\hline $\mathrm{F}_{7} \mathrm{C}_{3} \mathrm{P}-1$ & 6.4 & 0 & 4.8 & 0 & 0 \\
\hline $\mathrm{F}_{10} \mathrm{C}_{3} \mathrm{P}-1$ & 8.4 & 0 & 11.3 & 0 & 0 \\
\hline $\mathrm{F}_{14} \mathrm{C}_{3} \mathrm{P}-1$ & 12.0 & 0 & 15.7 & 0 & 0 \\
\hline $\mathrm{F}_{18} \mathrm{C}_{3} \mathrm{P}-1$ & 17.9 & 0 & 22.5 & 0 & 0 \\
\hline $\mathrm{F}_{34} \mathrm{C}_{3} \mathrm{P}-1$ & 33.5 & 0 & 31.6 & 0 & 0 \\
\hline $\mathrm{F}_{34} \mathrm{C}_{3} * *$ & 61.2 & 6 & 47.3 & 0.45 & 0.009 \\
\hline $\mathrm{F}_{7} \mathrm{C}_{3} \mathrm{P}-2$ & 7.6 & 0 & 5.3 & 0 & 0 \\
\hline $\mathrm{F}_{7} \mathrm{C}_{10} \mathrm{P}-2$ & 6.2 & 0 & 4.5 & 0 & 0 \\
\hline $\mathrm{F}_{14} \mathrm{C}_{3} \mathrm{P}-2$ & 13.4 & 0 & 12.1 & 0 & 0 \\
\hline $\mathrm{F}_{18} \mathrm{C}_{3} \mathrm{P}-2$ & 17.8 & 0 & 26.1 & 0 & 0 \\
\hline $\mathrm{F}_{34} \mathrm{C}_{3} \mathrm{P}-2$ & 34.7 & 0 & 39.4 & 0 & 0 \\
\hline
\end{tabular}

* According to ICP-AES data, ${ }^{* *} \mathrm{Fe}_{3} \mathrm{O}_{4} / \mathrm{SWCNT}$. $H_{C}$-coercive force, $M_{S}$-saturation magnetization, $M_{R}$-residual magnetization. 

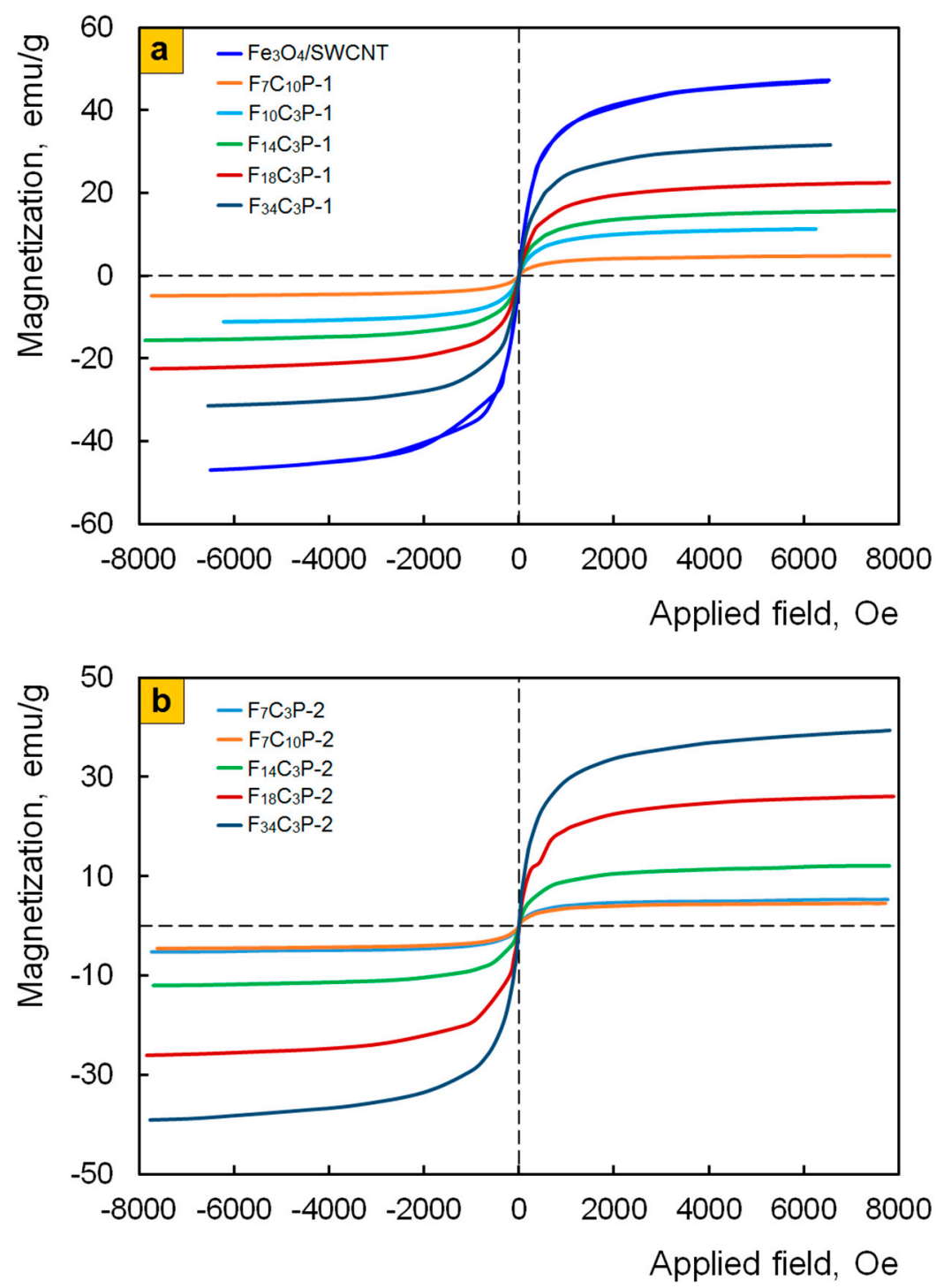

Figure 12. Magnetization of $\mathrm{Fe}_{3} \mathrm{O}_{4} / \mathrm{SWCNT}$ and $\mathrm{Fe}_{3} \mathrm{O}_{4} / \mathrm{SWCNT} / \mathrm{PDPAC}$, prepared in alkaline (a) and acidic media (b), as a function of applied magnetic field at room temperature.

It can be seen that, regardless of the preparation method, the $\mathrm{Fe}_{3} \mathrm{O}_{4} / \mathrm{SWCNT/PDPAC} \mathrm{nanocomposites}$ are superparamagnetic; this is due to the small size and high dispersion of magnetic nanoparticles [49,61]. The squareness ratio of the hysteresis loop is $\mathrm{K}_{S}=M_{R} / M_{S}=0$. The saturation magnetization $M_{S}$ depends on the content of magnetite nanoparticles and reaches 31.6-39.4 emu/g depending on the synthesis method of nanocomposites. An increase in the concentration of SWCNT to $10 \mathrm{wt}$. \% has little effect on the main magnetic parameters of the nanomaterials (Figure 12b).

The obtained hybrid nanomaterials can be promising as active components of magnetic fluids that are stable suspensions of magnetic nanoparticles in water or an organic solvent. Suspensions based on magnetic nanocomposites in ethanol were prepared. It was found that suspensions of $\mathrm{Fe}_{3} \mathrm{O}_{4} / \mathrm{SWCNT} / \mathrm{PDPAC}-1$ in ethanol remain stable for more than 8 months, whereas the $\mathrm{Fe}_{3} \mathrm{O}_{4} / \mathrm{SWCNT} / \mathrm{PDPAC}-2$ nanocomposites as well as $\mathrm{Fe}_{3} \mathrm{O}_{4} / \mathrm{SWCNT}$ dispersed in ethanol start sedimenting from the first minutes (Figure 13). 


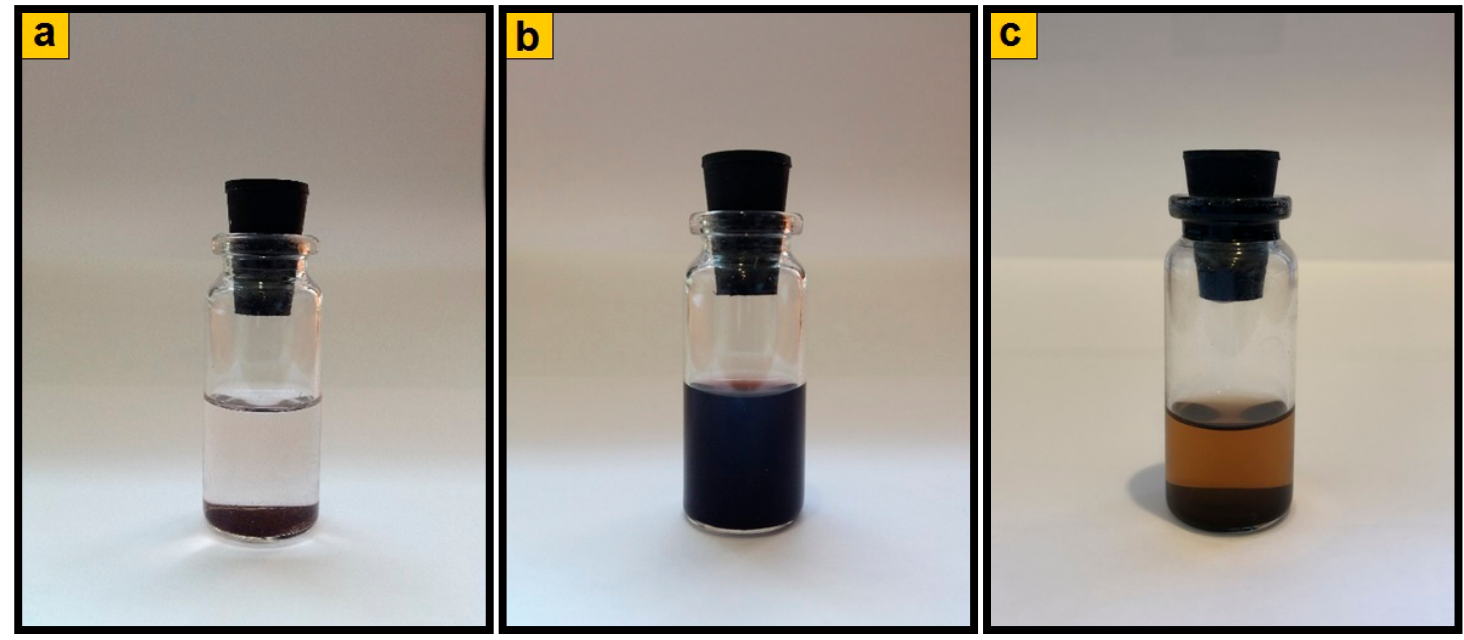

Figure 13. Suspensions of $\mathrm{Fe}_{3} \mathrm{O}_{4} / \mathrm{SWCNT}$ (a) and $\mathrm{Fe}_{3} \mathrm{O}_{4} / \mathrm{SWCNT/PDPAC}$, prepared in alkaline (b) and acidic media (c) in ethanol. (a,c) - in 5 min, (b) -in 8 months.

This behavior of the $\mathrm{Fe}_{3} \mathrm{O}_{4} / \mathrm{SWCNT/PDPAC}-1$ and $\mathrm{Fe}_{3} \mathrm{O}_{4} /$ SWCNT/PDPAC-2 nanocomposites is associated with the different chemical structures of the polymer component. The stability of the $\mathrm{Fe}_{3} \mathrm{O}_{4} / \mathrm{SWCNT} / \mathrm{PDPAC}-1$ suspension in ethanol is explained by the presence of a positive charge in the polymer shell structure of nanocomposites, which prevents the aggregation of magnetic nanoparticles. A positive charge can be formed both due to the charge transfer during the $\pi-\pi^{*}$ interaction of aromatic polymer units with the surface of $\mathrm{Fe}_{3} \mathrm{O}_{4} / \mathrm{SWCNT}$, and due to the electronic interaction of delocalized $\pi$-electrons with the free d-orbitals of an iron atom.

\section{Conclusions}

Ternary nanomaterials based on polydiphenylamine-2-carboxylic acid (PDPAC), single-walled carbon nanotubes (SWCNT), and magnetite nanoparticles in an acidic medium and in the interfacial process in an alkaline medium were obtained for the first time. The influence of the reaction medium $\mathrm{pH}$ on the structure, morphology, phase composition, thermal, electrical and magnetic properties of the obtained hybrid nanocomposites was studied. It was shown that the phase composition of $\mathrm{Fe}_{3} \mathrm{O}_{4} / \mathrm{SWCNT} / \mathrm{PDPAC}$ as well as the size and shape of $\mathrm{Fe}_{3} \mathrm{O}_{4}$ nanoparticles do not depend on the reaction medium $\mathrm{pH}$. The size of spherical $\mathrm{Fe}_{3} \mathrm{O}_{4}$ nanoparticles is within the range of $2<d<14 \mathrm{~nm}$. Regardless of the preparation method, the nanomaterials are superparamagnetic ( $\mathrm{K}_{S}=M_{R} / M_{S}=0$ ). The $\mathrm{Fe}_{3} \mathrm{O}_{4} / \mathrm{SWCNT/PDPAC}$ nanomaterials lose half of their initial weight in an inert atmosphere at temperatures above $900{ }^{\circ} \mathrm{C}$. Electrical conductivity of the nanomaterials depends strongly on the synthesis method as well as on the concentration both of carbon nanotubes and of $\mathrm{Fe}_{3} \mathrm{O}_{4}$ nanoparticles. At the same time, at low frequencies, the electrical conductivity of $\mathrm{Fe}_{3} \mathrm{O}_{4} / \mathrm{SWCNT/PDPAC}-2$ nanocomposites is significantly higher than the conductivity of $\mathrm{Fe}_{3} \mathrm{O}_{4} / \mathrm{SWCNT/PDPAC}-1$ due to the polymer matrix doping in an acidic medium. It was shown that, unlike $\mathrm{Fe}_{3} \mathrm{O}_{4} / \mathrm{SWCNT} / \mathrm{PDPAC}-2$, the $\mathrm{Fe}_{3} \mathrm{O}_{4} / \mathrm{SWCNT/PDPAC-1}$ nanomaterials prepared in an alkaline medium form magnetic fluids in ethanol; this is connected with differences in the chemical structure of the polymer component. Therefore, the results indicate that prepared hybrid electromagnetic nanomaterials have potential applications in the manufacture of sensors, supercapacitors, rechargeable batteries, anti-corrosion coatings, materials absorbing electromagnetic radiation, etc. The ability of powders of the prepared ternary hybrid nanocomposites to form suspensions in water and organic media allows to obtain the nanocomposite-based coatings on smooth and rough surfaces. Furthermore, these ternary nanocomposite-based suspensions can be applied for the impregnation of porous supports. These processing methods are important at fabrication of electrodes for chemical current sources and energy storage, electromagnetic shielding, sensor sensitive elements, anti-corrosion protection, etc. 
Author Contributions: S.Z.O. proposed synthesis methods for novel hybrid nanomaterials, conducted the experiments, analyzed the data, interpreted the results, and prepared the manuscript paper. G.P.K. revised and edited the manuscript. A.I.K. conducted the experiments, analyzed the data, and prepared the figures. P.A.C. and A.A.V. conducted the investigation of nanocomposites by magnetometry and X-ray diffraction. D.G.M. measured the AC conductivity. All authors have read and agreed to the published version of the manuscript.

Funding: This research received no external funding.

Acknowledgments: This work was carried out within the State Program of TIPS RAS. This work was performed using the equipment of the Shared Research Center «Analytical center of deep oil processing and petrochemistry of TIPS RAS».

Conflicts of Interest: The authors declare no conflicts of interest.

\section{References}

1. Sellinger, A.; Weiss, P.M.; Nguyen, A.; Lu, Y.; Assink, R.A.; Gong, W.; Brinker, C.J. Continuous self-assembly of organic-inorganic nanocomposite coatings that mimic nacre. Nature 1998, 394, 256-259. [CrossRef]

2. Yamamoto, K.; Sakata, Y.; Nohara, Y.; Takashi, Y.; Tatsumi, T. Organic-inorganic hybrid zeolites containing organic frameworks. Science 2003, 300, 470-472. [CrossRef]

3. Balazs, A.C.; Emrick, T.; Russel, T.P. Nanoparticle polymer composites: Where two small worlds meet. Science 2006, 314, 1107-1110. [CrossRef]

4. Karpacheva, G.P. Hybrid magnetic nanocomposites including polyconjugated polymers. Polym. Sci. C 2016, 58, 131-146.

5. Zheng, Y.; Wang, X.; Wu, G. Chemical modification of carbon fiber with diethylenetriaminepentaacetic acid/halloysite nanotube as a multifunctional interfacial reinforcement for silicone resin composites. Polym. Adv. Technol. 2020, 31, 527-535. [CrossRef]

6. Zheng, Y.; Chen, L.; Wang, X.; Wu, G. Modification of renewable cardanol onto carbon fiber for the improved interfacial properties of advanced polymer composites. Polymers 2020, 12, 45. [CrossRef]

7. Godovsky, D.Y. Device applications of polymer-nanocomposites. Adv. Polym. Sci. 2000, 153, $163-205$.

8. Gerasin, V.A.; Antipov, E.M.; Karbushev, V.V.; Kulichikhin, V.G.; Karpacheva, G.P.; Talroze, R.V.; Kudryavtsev, Y.V. New approaches to the development of hybrid nanocomposites: From structural materials to high-tech applications. Russ. Chem. Rev. 2013, 82, 303-332. [CrossRef]

9. Yang, J.; Liu, Y.; Liu, S.; Li, L.; Zhang, C.; Liu, T. Conducting polymer composites: Material synthesis and applications in electrochemical capacitive energy storage. Mater. Chem. Front. 2017, 1, 251-268. [CrossRef]

10. Lyu, L.; Liu, J.; Liu, H.; Liu, C.; Lu, Y.; Sun, K.; Fan, R.; Wang, N.; Guo, Z.; Wujcik, E.K. An overview of electrically conductive polymer nanocomposites toward electromagnetic interference shielding. Eng. Sci. 2018, 2, 26-42.

11. Zhao, B.; Deng, J.; Zhang, R.; Liang, L.; Fan, B.; Bai, Z.; Shao, G.; Park, C.B. Recent advances on the electromagnetic wave absorption properties of Ni based materials. Eng. Sci. 2018, 3, 5-40. [CrossRef]

12. He, Y.; Chen, Q.; Yang, S.; Lu, C.; Feng, M.; Jiang, Y.; Cao, G.; Zhang, J.; Liu, C. Micro-crack behavior of carbon fiber reinforced $\mathrm{Fe}_{3} \mathrm{O}_{4}$ /graphene oxide modified epoxy composites for cryogenic application. Compos. Part $A$ Appl. Sci. Manuf. 2018, 108, 12-22. [CrossRef]

13. Wang, C.; Murugadoss, V.; Kong, J.; He, Z.; Mai, X.; Shao, Q.; Chen, Y.; Guo, L.; Liu, C.; Angaiah, S.; et al. Overview of carbon nanostructures and nanocomposites for electromagnetic wave shielding. Carbon 2018, 140, 696-733. [CrossRef]

14. Chen, J.; Yu, Q.; Cui, X.; Dong, M.; Zhang, J.; Wang, C.; Fan, J.; Zhu, Y.; Guo, Z. An overview of stretchable strain sensors from conductive polymer nanocomposites. J. Mater. Chem. C 2019, 7, 11710-11730. [CrossRef]

15. Wen, N.; Jiang, B.; Wang, X.; Shang, Z.; Jiang, D.; Zhang, L.; Sun, C.; Wu, Z.; Yan, H.; Liu, C.; et al. Overview of polyvinyl alcohol nanocomposite hydrogels for electro-skin, actuator, supercapacitor and fuel cell. Chem. Rec. 2020. [CrossRef]

16. Wei, H.; Wang, H.; Cui, D.; Zhao, Z.; Chu, L.; Wei, X.; Wang, L.; Pan, D.; Fan, J.; Li, Y.; et al. Multifunctions of polymer nanocomposites: Environmental remediation, electromagnetic interference shielding, and sensing applications. ChemNanoMat 2020, 6, 174-184. [CrossRef]

17. Zhang, L.; Du, W.Y.; Nautiyal, A.; Liu, Z.; Zhang, X.Y. Recent progress on nanostructured conducting polymers and composites: Synthesis, application and future aspects. Sci. China Mater. 2018, 61, 303-352. [CrossRef] 
18. Jiang, D.W.; Murugadoss, V.; Wang, Y.; Lin, J.; Ding, T.; Wang, Z.C.; Shao, Q.; Wang, C.; Liu, H.; Lu, N. Electromagnetic interference shielding polymers and nanocomposites-A Review. Polym. Rev. 2019, 59, 280-337. [CrossRef]

19. Zhang, Y.J.; Lin, Y.W.; Chang, C.C.; Wu, T.M. Conducting and magnetic behaviors of polyaniline coated multi-walled carbon nanotube composites containing monodispersed magnetite nanoparticles. Synth. Met. 2011, 161, 937-942. [CrossRef]

20. Chen, T.; Qiu, J.; Zhu, K.; Che, Y.; Zhang, Y.; Zhang, J.; Li, H.; Wang, F.; Wang, Z. Enhanced electromagnetic wave absorption properties of polyaniline-coated $\mathrm{Fe}_{3} \mathrm{O}_{4} /$ reduced graphene oxide nanocomposites. J. Mater. Sci. Mater. Electron. 2014, 25, 3664-3673. [CrossRef]

21. Zhou, H.; Wang, X.; Yu, K.; Zhang, C.; Li, H.; Du, Z. Preparation of multi-walled carbon nanotube/polyaniline/ $\mathrm{Fe}_{3} \mathrm{O}_{4}$ composites. Integr. Ferroelectr. 2014, 154, 159-165. [CrossRef]

22. Liu, P.; Huang, Y.; Zhang, X. Superparamagnetic $\mathrm{Fe}_{3} \mathrm{O}_{4}$ nanoparticles on graphene-polyaniline: Synthesis, characterization and their excellent electromagnetic absorption properties. J. Alloys Compd. 2014, 596, 25-31. [CrossRef]

23. Wu, T.M.; Yen, S.J.; Chen, E.C.; Chiang, R.K. Synthesis, characterization, and properties of monodispersed magnetite coated multi-walled carbon nanotube/polypyrrole nanocomposites synthesized by in-situ chemical oxidative polymerization. J. Polym. Sci. B Polym. Phys. 2008, 46, 727-733. [CrossRef]

24. He, Z.; Fang, Y.; Wang, X.; Pang, H. Microwave absorption properties of PANI/CIP/ $/ \mathrm{Fe}_{3} \mathrm{O}_{4}$ composites. Synth. Met. 2011, 161, 420-425. [CrossRef]

25. Liu, P.; Huang, Y.; Wang, L.; Zhang, W. Preparation and excellent microwave absoption property of three component nanocompostes: Polyaniline-reduced graphene oxide- $\mathrm{Co}_{3} \mathrm{O}_{4}$ nanoparticles. Synth. Met. 2013, 177, 89-93. [CrossRef]

26. Yang, R.B.; Reddy, P.M.; Chang, C.J.; Chen, P.A.; Chen, J.K.; Chang, C.C. Synthesis and characterization of $\mathrm{Fe}_{3} \mathrm{O}_{4}$ /polypyrrole/carbon nanotube composites with tunable microwave absorption properties: Role of carbon nanotube and polypyrrole content. Chem. Eng. J. 2016, 285, 497-507. [CrossRef]

27. Ma, Y.; Zhou, Y.; Sun, Y.; Chen, H.; Xiong, Z.; Li, X.; Shen, L.; Liu, Y. Tunable magnetic properties of $\mathrm{Fe}_{3} \mathrm{O}_{4} / \mathrm{rGO} / \mathrm{PANI}$ nanocomposites for enhancing microwave absorption performance. J. Alloys Compd. 2019, 796, 120-130. [CrossRef]

28. Wang, S.; Bao, H.; Yang, P.; Chen, G. Immobilization of trypsin in polyaniline-coated nano-Fe $\mathrm{O}_{4} / \mathrm{carbon}$ nanotube composite for protein digestion. Anal. Chim. Acta 2008, 612, 182-189. [CrossRef]

29. Radhakrishnan, S.; Krishnamoorthy, K.; Sekar, C.; Wilson, J.; Kim, S.J. A promising sensing platform on ternary composite of polyaniline- $\mathrm{Fe}_{2} \mathrm{O}_{3}$-reduced graphene oxide for sensitive hydroquinone determination. Chem. Eng. J. 2015, 259, 594-602. [CrossRef]

30. Giri, S.; Ghosh, D.; Das, C.K. In situ synthesis of cobalt doped polyaniline modified graphene composites for high performance supercapacitor electrode materials. J. Electroanal. Chem. 2013, 697, 32-45. [CrossRef]

31. Xiong, P.; Huang, H.; Wang, X. Design and synthesis of ternary cobalt ferrite/graphene/polyaniline hierarchical nanocomposites for high-perfomance supercapacitors. J. Power Sources 2014, 245, 937-946. [CrossRef]

32. Lin, H.; Huang, Q.; Wang, J.; Jiang, J.; Liu, F.; Chen, Y.; Wang, C.; Lu, D.; Han, S. Self-assembled graphene/polyaniline/ $\mathrm{Co}_{3} \mathrm{O}_{4}$ ternary hybrid aerogels for supercapacitors. Electrochim. Acta 2016, 191, 444-451. [CrossRef]

33. Ren, G.; Li, Y.; Guo, Z.; Xiao, G.; Zhu, Y.; Dai, L.; Jiang, L. A bio-inspired $\mathrm{Co}_{3} \mathrm{O}_{4}$-polypyrrole-graphene complex as an efficient oxygen reduction catalyst in one-step ball milling. Nano Res. 2015, 8, 3461-3471. [CrossRef]

34. Liu, Y.; Li, J.; Li, F.; Li, W.; Yang, H.; Zhang, X.; Liu, Y.; Ma, J. A facile preparation of $\mathrm{CoFe}_{2} \mathrm{O}_{4}$ nanoparticles on polyaniline-functionalised carbon nanotubes as enhanced catalysts for the oxygen evolution reaction. J. Mater. Chem. A 2016, 4, 4472-4478. [CrossRef]

35. Zhao, C.; Jin, Y.; Du, X.; Du, W. In situ prepared amorphous FeCoO- polyaniline/multiwalled carbon nanotube nanohybrids as efficient oxygen evolution catalysts for rechargeable $\mathrm{Zn}$-air batteries. J. Power. Sources 2018, 399, 337-342. [CrossRef]

36. Zhu, A.; Shi, P.; Sun, S.; Rui, M. Construction of $\mathrm{rGO} / \mathrm{Fe}_{3} \mathrm{O}_{4} / \mathrm{PANI}$ nanocomposites and its corrosion resistance mechanism in waterborne acrylate-amino coating. Prog. Org. Coat. 2019, 133, 117-124. [CrossRef] 
37. Singh, A.P.; Mishra, M.; Sambyal, P.; Gupta, B.K.; Singh, B.P.; Chandra, A.; Dhawan, S.K. Encapsulation of $\gamma-\mathrm{Fe}_{2} \mathrm{O}_{3}$ decorated reduced graphene oxide in polyaniline core-shell tubes as an exceptional tracker for electromagnetic environmental pollution. J. Mater. Chem. A 2014, 2, 3581-3593. [CrossRef]

38. Ibrahim, A.; Abdel-Aziz, M.H.; Zorombam, M.S.; Al-Hossainy, A.F. Structural, optical, and electrical properties of multi-walled carbon nanotubes/polyaniline/ $\mathrm{Fe}_{3} \mathrm{O}_{4}$ ternary nanocomposites thin film. Synth. Met. 2018, 238, 1-13. [CrossRef]

39. Kong, L.; Lu, X.; Zhang, W. Facile synthesis of multifunctional multiwalled carbon nanotubes $/ \mathrm{Fe}_{3} \mathrm{O}_{4}$ nanoparticles/polyaniline composite nanotubes. J. Solid State Chem. 2008, 181, 628-636. [CrossRef]

40. Cao, M.S.; Yang, J.; Song, W.L.; Zhang, D.Q.; Wen, B.; Jin, H.B.; Hou, Z.L.; Yuan, J. Ferroferric oxide/multiwalled carbon nanotube vs polyaniline/ferroferric oxide/multiwalled carbon nanotube multiheterostructures for highly effective microwave absorption. ACS Appl. Mater. Interfaces 2012, 4, 6949-6956. [CrossRef]

41. Dai, L.; Mau, A.V.H. Controlled synthesis and modification of carbon nanotubes and $\mathrm{C}_{60}$ : Carbon nanostructures for advanced polymeric composite materials. Adv. Mater. 2001, 13, 899-913. [CrossRef]

42. Baughman, R.H.; Zakhidov, A.A.; de Heer, W.A. Carbon nanotubes-The route toward applications. Science 2002, 297, 787-792. [CrossRef]

43. Ozkan, S.Z.; Karpacheva, G.P.; Chernavskii, P.A.; Dzidziguri, E.L.; Bondarenko, G.N.; Pankina, G.V. Hybrid materials based on poly-3-amine-7-methylamine-2-methylphenazine and magnetite nanoparticles immobilized on single-walled carbon nanotubes. Polymers 2018, 10, 544. [CrossRef] [PubMed]

44. Ozkan, S.Z.; Eremeev, I.S.; Karpacheva, G.P.; Bondarenko, G.N. Oxidative polymerization of N-phenylanthranilic acid in the heterophase system. Open J. Polym. Chem. 2013, 3, 63-69. [CrossRef]

45. Massart, R. Preparation of aqueous magnetic liquids in alkaline and acidic media. IEEE Trans. Magn. 1981, 17, 1247-1248. [CrossRef]

46. Ozkan, S.Z.; Bondarenko, G.N.; Karpacheva, G.P. Oxidative polymerization of diphenylamine-2-carboxylic acid: Synthesis, structure, and properties of polymers. Polym. Sci. B 2010, 52, 263-269. [CrossRef]

47. Ozkan, S.Z.; Eremeev, I.S.; Karpacheva, G.P.; Prudskova, T.N.; Veselova, E.V.; Bondarenko, G.N.; Shandryuk, G.A. Polymers of dipheylamine-2-carboxylic acid: Synthesis, structure and properties. Polym. Sci. B 2013, 55, 107-115.

48. Dzidziguri, E.L. Dimensional characteristics of nanopowders. Nanotechnologies Russ. 2009, 4, 857-870. [CrossRef]

49. Chernavskii, P.A.; Pankina, G.V.; Lunin, V.V. Magnetometric methods of investigation of supported catalysts. Russ. Chem. Rev. 2011, 80, 579-604. [CrossRef]

50. Soloveva, A.Y.; Ioni, Y.V.; Gubin, S.P. Synthesis of $\mathrm{Fe}_{3} \mathrm{O}_{4}$ nanoparticles on the surface of graphene. Mendeleev Commun. 2016, 26, 38-39. [CrossRef]

51. Abrosimova, G.E.; Aronin, A.S.; Kholstinina, N.N. On the determination of the volume fraction of the crystalline phase in amorphous-crystalline alloys. Phys. Solid State 2010, 52, 445-451. [CrossRef]

52. Ozkan, S.Z.; Karpacheva, G.P.; Kostev, A.I.; Bondarenko, G.N. Formation features of hybrid nanocomposites based on polydiphenylamine-2-carboxylic acid and single-walled carbon nanotubes. Polymers 2019, 11, 1181. [CrossRef]

53. Zengin, H.; Zhou, W.; Jin, J.; Czerw, R.; Smith, D.W., Jr.; Echegoyen, L.; Carroll, D.L.; Foulger, S.H.; Ballato, J. Carbon nanotube doped polyaniline. Adv. Mater. 2002, 14, 1480-1483. [CrossRef]

54. Cochet, M.; Maser, W.K.; Benito, A.M.; Callejas, M.A.; Martínez, M.T.; Benoit, J.-M.; Schreiber, J.; Chauvet, O. Synthesis of a new polyaniline/nanotube composite: "in-situ" polymerisation and charge transfer through site-selective interaction. Chem. Commun. 2001, 37, 1450-1451. [CrossRef]

55. Xu, J.; Yao, P.; Liu, L.; Jiang, Z.; He, F.; Li, M.; Zou, J. Synthesis and characterization of an organic soluble and conducting polyaniline-grafted multiwalled carbon nanotube core-shell nanocomposites by emulsion polymerization. J. Appl. Polym. Sci. 2010, 118, 2582-2591. [CrossRef]

56. Jonscher, A.K. The 'universal' dielectric response. Nature 1977, 267, 673-679. [CrossRef]

57. Dyre, J.C.; Schrøder, T.B. Universality of ac conduction in disordered solids. Rev. Mod. Phys. 1999, 72, 873-892. [CrossRef]

58. Xie, P.; Li, Y.; Hou, Q.; Sui, K.; Liu, C.; Fu, X.; Zhang, J.; Murugadoss, V.; Fan, J.; Wang, Y.; et al. Tunneling-induced negative permittivity in $\mathrm{Ni} / \mathrm{MnO}$ nanocomposites by a bio-gel derived strategy. J. Mater. Chem. C. 2020, 8, 3029-3039. [CrossRef] 
59. Rehwald, W.; Kiess, H.; Binggeli, B. Frequency dependent conductivity in polymers and other disordered materials. Z. Phys. B Condens. Matter. 1987, 68, 143-148. [CrossRef]

60. Dyre, J.C. The random free-energy barrier model for ac conduction in disordered solids. J. Appl. Phys. 1988, 64, 2456-2468. [CrossRef]

61. Gubin, S.P.; Koksharov, Y.A.; Khomutov, G.B.; Yurkov, G.Y. Magnetic nanoparticles: Preparation, structure and properties. Russ. Chem. Rev. 2005, 7, 489-520. [CrossRef] 